\title{
Differential Properties of Astrocyte Calcium Waves Mediated by P2Y1 and P2Y2 Receptors
}

\author{
Conor J. Gallagher ${ }^{1,3}$ and Michael W. Salter ${ }^{1,2,3}$ \\ ${ }^{1}$ Programme in Brain and Behaviour, Hospital For Sick Children, ${ }^{2}$ Department of Physiology, and ${ }^{3}$ Institute of Medical Science, University of Toronto, \\ Toronto, Ontario M5G 1X8, Canada
}

Intercellular spread of $\mathrm{Ca}^{2+}$ waves is the primary manifestation of cell-to-cell communication among astrocytes. $\mathrm{Ca}^{2+}$ waves propagate via the release of a diffusible extracellular messenger that has been identified as ATP. In dorsal spinal astrocytes, Ca ${ }^{2+}$ waves are mediated by activation of two functionally distinct subtypes of metabotropic purinoceptor: the P2Y1 receptor and a receptor previously classified as P2U. Here, we show that the P2U receptor is molecularly and pharmacologically identical to the cloned P2Y2 receptor. Both $\mathrm{P} 2 \mathrm{Y} 1$ and $\mathrm{P} 2 \mathrm{Y} 2$ receptors are necessary for full $\mathrm{Ca}^{2+}$ wave propagation in spinal astrocytes. Conversely, heterologous expression of either $\mathrm{P} 2 \mathrm{Y} 1$ or $\mathrm{P} 2 \mathrm{Y} 2$ receptors is sufficient for $\mathrm{Ca}^{2+}$ waves, and expressing these receptor subtypes together recapitulates the characteristics of $\mathrm{Ca}^{2+}$ waves in spinal astrocytes. Thus, P2Y1 and P2Y2 receptors are both necessary and sufficient for propagation of Ca ${ }^{2+}$ waves. Furthermore, we demonstrate that there are dramatic differences in the characteristics of $\mathrm{Ca}^{2+}$ waves propagating through each receptor subtype: $\mathrm{Ca}^{2+}$ waves propagating via $\mathrm{P} 2 \mathrm{Y} 2$ receptors travel faster and further than those propagating via $\mathrm{P} 2 \mathrm{Y} 1$ receptors. We find that the nucleotidase apyrase selectively blocks $\mathrm{Ca}^{2+}$ wave propagation through $\mathrm{P} 2 \mathrm{Y} 2$ receptors but accelerates $\mathrm{Ca}^{2+}$ waves propagating through $\mathrm{P} 2 \mathrm{Y} 1$ receptors. Taking our results together with those from the literature, we suggest that mediation of $\mathrm{Ca}^{2+}$ waves by ATP leading to activation of two subtypes of receptor, $\mathrm{P} 2 \mathrm{Y} 1$ and $\mathrm{P} 2 \mathrm{Y} 2$, may be a general principle for gliotransmission in the CNS. Thus, processes that alter expression or function of these receptors may control the rate and extent of astrocyte $\mathrm{Ca}^{2+}$ waves.

Key words: $\mathrm{Ca}^{2+}$ waves; astrocytes; purinoceptors; spinal cord; apyrase; imaging

\section{Introduction}

In astrocyte networks, elevations in intracellular $\left[\mathrm{Ca}^{2+}\right]$ $\left(\left[\mathrm{Ca}^{2+}\right]_{\mathrm{i}}\right)$ propagate from one cell to another as spreading $\mathrm{Ca}^{2+}$ waves (Cornell-Bell et al., 1990; Charles et al., 1991). $\mathrm{Ca}^{2+}$ signaling in astrocytes is a principal means for responding to environmental stimuli, and increases in $\left[\mathrm{Ca}^{2+}\right]_{\mathrm{i}}$ lead to growth, differentiation, and release of neuroactive mediators (Vernadakis, 1996). Spread of $\mathrm{Ca}^{2+}$ waves may underlie an astrocyte-based long-range signaling system in the CNS. The passage of $\mathrm{Ca}^{2+}$ waves through astrocyte networks has been shown to influence the efficacy of neurotransmission at adjacent synapses (Nedergaard, 1994; Newman and Zahs, 1998), and neuronal activity has been shown to evoke $\mathrm{Ca}^{2+}$ elevations in astrocytes (Araque et al., 2002). Thus, $\mathrm{Ca}^{2+}$ waves may be a mechanism for encoding and transmitting information that complements and interacts with electrical signaling of neurons (Bezzi and Volterra, 2001).

Astrocyte $\mathrm{Ca}^{2+}$ waves have been shown to propagate by means of a diffusible extracellular messenger (Hassinger et al., 1996; Guthrie et al., 1999). A growing body of evidence has im-

Received April 3, 2003; revised May 27, 2003; accepted May 28, 2003.

This work was supported by grants from the Canadian Institutes of Health Research (M.W.S.) and the Ontario Neurotrauma Foundation (C.J.G.). C.J.G. is a clinician-scientist trainee at the Hospital for Sick Children, and M.W.S. is a Canadian Institutes of Health Research investigator. We thank J. L. Hicks and David Wong for preparing and maintaining dorsal horn cultures. We also thank Dr. G. I. Bell for the rat P2Y1 CDNA and Dr.Z.-P. Chen for the rat P2Y2 CDNA.

Correspondence should be addressed to Michael W. Salter, Programme in Brain and Behaviour, The Hospital for Sick Children, 555 University Avenue, Toronto, Ontario M5G 1X8, Canada. E-mail: mike.salter@utoronto.ca. Copyright $\odot 2003$ Society for Neuroscience $\quad$ 0270-6474/03/236728-12\$15.00/0 plicated ATP as the principal messenger mediating $\mathrm{Ca}^{2+}$ wave propagation: ATP is released from astrocytes during $\mathrm{Ca}^{2+}$ wave propagation (Cotrina et al., 1998a; Guthrie et al., 1999); applying ATP evokes $\mathrm{Ca}^{2+}$ responses in astrocytes (Neary et al., 1988; Salter and Hicks, 1994); and $\mathrm{Ca}^{2+}$ waves are blocked by antagonists of ATP-activated metabotropic receptors [P2Y receptors (P2YRs)] (Guan et al., 1997; Cotrina et al., 1998a; Guthrie et al., 1999; Fam et al., 2000). This evidence leads to a model for $\mathrm{Ca}^{2+}$ wave propagation whereby ATP is released from astrocytes and activates P2YRs.

$\mathrm{P} 2 \mathrm{Y}$ receptors are the subclass of the G-protein-coupled receptor superfamily that are activated by extracellular nucleotides, including ATP. The P2YR family comprises seven confirmed gene products: $\mathrm{P} 2 \mathrm{Y} 1,2,4,6$, and 11-13. Astrocytes express two functional subtypes of P2YR (Ho et al., 1995) both of which are necessary for full propagation of $\mathrm{Ca}^{2+}$ waves (Fam et al., 2000). One of these receptors has been identified pharmacologically and molecularly as the cloned P2Y1R (Fam et al., 2000). The P2Y1R is activated by ATP and ADP but not by UTP or UDP. The other subtype of P2YR expressed by astrocytes has been functionally classified as P2U because it is activated equipotently by UTP and ATP but is unaffected by ADP or UDP (Ho et al., 1995). However, the pharmacological profile of the UTP-mediated responses of astrocytes does not match that previously reported for any cloned $\mathrm{P} 2 \mathrm{YR}$. Thus, the molecular identity of the $\mathrm{P} 2 \mathrm{U}$ receptor, which is critical for astrocyte $\mathrm{Ca}^{2+}$ wave propagation, remains unknown.

In the present study, we clarify the pharmacological properties 
of $\mathrm{Ca}^{2+}$ responses mediated by UTP-sensitive P2YRs from the rat and show molecularly and pharmacologically that the receptor mediating the UTP responses of astrocytes is P2Y2. Furthermore, we have discovered that $\mathrm{Ca}^{2+}$ waves mediated by $\mathrm{P} 2 \mathrm{Y} 2 \mathrm{Rs}$ propagate dramatically faster than do those mediated via P2Y1Rs. We have determined that, on activation by ATP, P2Y2Rs generate a rise in $\left[\mathrm{Ca}^{2+}\right]_{\mathrm{i}}$ more rapidly than do P2Y1Rs, and this underlies the differential rates of $\mathrm{Ca}^{2+}$ wave propagation.

\section{Materials and Methods}

Cell culture. Primary dissociated cultures of dorsal spinal cord were prepared from embryonic day 17-18 rats and maintained as described in detail elsewhere (Salter and Hicks, 1994). Briefly, timed pregnant Wistar rats were anesthetized, and embryos were removed surgically. The spinal cord was extracted from each embryo, and the dura was removed. Dorsal horn tissue was isolated according to the "open-book" technique (Peterson and Crain, 1982). The dorsal half of the cord was then incubated in $0.25 \%$ trypsin for $30 \mathrm{~min}$, rinsed, mechanically dissociated by trituration, and then plated onto collagen-coated plastic disks affixed over holes in 35 $\mathrm{mm}$ culture dishes (recording dishes). Cells were maintained in DMEM (Invitrogen, San Diego, CA) supplemented with 10\% fetal bovine serum (FBS) and 10\% horse serum for 1 week. After 1 week, the media were switched to DMEM plus $10 \%$ horse serum. Cells were used at $10-15 \mathrm{~d}$ in culture.

Reverse transcription-PCR screening of dorsal spinal cord cultures for novel UTP-activated receptors. To identify novel UTP-activated P2YRs in dorsal spinal cord cultures, we performed reverse transcription (RT) followed by nested PCR using degenerate primers designed against known UTP-activated P2YRs. RNA was harvested from dorsal spinal cord cultures using the TRIzol method (Invitrogen). Reverse transcription was performed on this RNA with the Superscript reverse transcription kit (Invitrogen) using oligo-dT primers to selectively transcribe mRNA. For nested PCR, two primer pairs were used. The first primer was a degenerate upstream primer, which was designed to the third transmembrane (Tm3) region of $\mathrm{P} 2 \mathrm{Y} 1,2,4$, and 6 . The sequence of this primer was 5'-TCC TC/G/TT TCA CCT GCA T-3'. Two degenerate downstream primers were made, which were designed against regions of high sequence homology in P2YRs activated by UTP, namely P2Y2, 4, and 6 . One primer was made to the $\mathrm{Tm} 5$ domain and had a sequence of 5'-A/GCA GC/G/TC GC/G/TC GGG CCA TG-3', whereas the other primer was designed to the Tm6 domain and had a sequence of $5^{\prime}$-GGA AA/GG GCA C/GGA AGC-3'. Poly $\left(\mathrm{A}^{+}\right)$cDNA from dorsal spinal cultures was used as the template for a first PCR, which used the Tm3 and Tm6 primer pair. The PCR conditions were 94,52 , and $72^{\circ} \mathrm{C}$ for $1 \mathrm{~min}$ each for 30 cycles with a $\left[\mathrm{Mg}^{2+}\right]$ of $2 \mathrm{~mm}$. After this reaction, $1 \mu \mathrm{l}$ of the previous reaction was used as the template for PCR using the Tm 3 and $\mathrm{Tm} 5$ primer pair. This reaction was run for 30 cycles of 94,53 , and $72^{\circ} \mathrm{C}$ for $1 \mathrm{~min}$ at each temperature with a $\left[\mathrm{Mg}^{2+}\right]$ of $1.25 \mathrm{~mm}$. The products of this reaction were run on an agarose gel stained with ethidium bromide. DNA bands visualized under UV light were excised from the gel and purified using the QIAquick gel extraction kit (Qiagen, Hilden, Germany). Purified DNA was then ligated into the PCR-blunt II-TOPO vector using the Zero-blunt TOPO cloning kit (Invitrogen), and then sequenced.

Cloning of rat P2Y4. The published sequence of rat P2Y4 does not contain introns (Bogdanov et al., 1998); therefore, to obtain P2Y4 cDNA, we elected to clone the receptor from rat genomic DNA. Genomic DNA was isolated from rat liver and purified using the TRIzol method (Invitrogen). Oligonucleotide primers were designed to regions flanking the start codon and the polyadenylated $3^{\prime}$ end of the sequence. To facilitate the subcloning process, a $\mathrm{Bam} \mathrm{H} 1$ restriction site was designed into the upstream primer (5'-GGA TCC ATG ACC AGT GCA GAA TCC-3'), and an $X h o I$ restriction site was included in the downstream primer (5'-CTC GAG TTA GTT CCC TTC ATA TCC AGC-3'). PCR was performed on rat genomic DNA, and the product of the PCR was run on an agarose gel. A band corresponding to the predicted size was identified and excised from the gel. The DNA contained within this band was purified using the Qiapure method and was ligated into the PCR-blunt II vector (Invitrogen). This was then sequenced to confirm that the PCR product was identical to the published sequence for rat $\mathrm{P} 2 \mathrm{Y} 4$ and that it contained the appropriate restriction sites. The introduced restriction sites were used to excise the coding region of P2Y4 from PCR-blunt II, and this was then ligated into the mammalian expression vector pcDNA3 (Invitrogen). The product of this ligation was then sequenced to determine that the sequence was still correct. Bacteria were transformed with rP2Y4-pcDNA3 and were allowed to multiply. The vector DNA was then isolated and purified using the Maxi-prep kit and protocol (Qiagen).

Generation and maintenance of 1321N1 human astrocytoma cell lines stably expressing P2Y1 and P2Y2. Recombinant receptors were expressed in $1321 \mathrm{~N} 1$ human astrocytoma cells (obtained from the European Collection of Cell Cultures), a cell line that does not express receptors activated by nucleotides (Parr et al., 1994). We used a stable cell line expressing rat P2Y1 (rP2Y1) purinoceptor cDNA (GenBank accession number U22830; from Dr. G. I. Bell, University of Chicago, Chicago, IL) subcloned into the mammalian expression vector pcDNA3, generated as described previously (Fam et al., 2000). To generate a 1321N1 cell line expressing P2Y2, rP2Y2 (GenBank accession number L46165; from Dr. Z.-P. Chen, Robert Wood Johnson Medical School, Pisataway, NJ) was subcloned into the EcoRI-XhoI restriction sites of the mammalian expression vector pcDNA3 (Invitrogen). rP2Y2-pcDNA3 was grown in bacteria and purified and was then transfected into $1321 \mathrm{~N} 1$ cells using the calcium phosphate method (Sambrook and Russell, 2001). Transfected cells were grown in DMEM supplemented with 10\% FBS and 1\% penicillin and streptomycin. After $2 \mathrm{~d}$ of growth, the transfected cells were split 1:6 into media containing $500 \mathrm{mg} / \mathrm{ml} \mathrm{G} 418$ (Invitrogen; selection media). Media were exchanged every $2-3 \mathrm{~d}$, and the cells were grown in selection media for $14 \mathrm{~d}$. Isolated colonies of cells demonstrating resistance to G418 were picked and transferred to 24 -well plates, where they were grown in selection media to near confluence and then transferred to the recording dishes described above. After $24 \mathrm{hr}$ in recording dishes, cells were loaded with fura- 2 , and $\mathrm{Ca}^{2+}$ responses to applied UTP were used as an assay to determine cell lines expressing functional P2Y2Rs. In these lines, expression of P2Y2 mRNA was confirmed using RT-PCR. Cell lines found to be expressing P2Y2R were then maintained in normal medium supplemented with $400 \mathrm{mg} / \mathrm{ml} \mathrm{G418}$ and split 1:12 every 3-4 d. When required for experiments, cells were split and plated onto recording dishes and were used within $2 \mathrm{~d}$.

To generate fields of cells where P2Y1-1321N1 and P2Y2-1321N1 cells were comingled, equal starting concentrations of P2Y1-1321N1 and P2Y2-1321N1 cells were separately trypsinized and then resuspended in $5 \mathrm{ml}$ of G418 media. Two drops of each resuspended cell line were plated into a $35 \mathrm{~mm}$ recording dish, prepared as described above, containing 2 $\mathrm{ml}$ of G418 media. Cells were incubated for $48 \mathrm{hr}$ before use. Before initiating a $\mathrm{Ca}^{2+}$ wave in these cells, P2Y1- and P2Y2-expressing cells were identified in each field by brief focal application of the P2Y1Rselective agonist 2-methyl thio ADP (2meSADP) ( $5 \mu \mathrm{M})$ or the P2Y2Rselective agonist UTP $(50 \mu \mathrm{M})$. No cells tested responded to both agonists.

Although we endeavored to plate cells at a constant density in recording dishes, individual fields often contained differing numbers of cells; thus, it was possible that the density of the cells in each field influenced the rate of $\mathrm{Ca}^{2+}$ wave propagation. We tested this possibility by correlating the mean rate of $\mathrm{Ca}^{2+}$ wave propagation in each field with the number of cells in the field for P2Y1-1321N1, P2Y2-1321N1, and spinal astrocytes. The slope of the best fit regression lines were found to be $-0.12 \pm 0.1$ for P2Y1-1321N1 cells $\left(r^{2}=0.04 ; p=0.35\right),-0.22 \pm 0.3$ for P2Y2-1321N1 cells $\left(r^{2}=0.03 ; p=0.47\right)$, and $0.11 \pm 0.6\left(r^{2}=0.16\right.$; $p=0.85)$ for spinal cord astrocytes. The correlation coefficients calculated indicate that there is no correlation between the rates of $\mathrm{Ca}^{2+}$ wave propagation in $\mathrm{P} 2 \mathrm{Y} 1-1321 \mathrm{~N} 1$ cells, $\mathrm{P} 2 \mathrm{Y} 2-1321 \mathrm{~N} 1$ cells, and spinal astrocytes and the cell density in each field.

Transient transfection. Native $1321 \mathrm{~N} 1$ cells were transiently transfected with rP2Y1-pcDNA3, rP2Y2-pcDNA3, or rP2Y4-pcDNA3 using the Superfect transfection kit (Qiagen) following the protocol specified therein. For cotransfection of two separate plasmids into cells, the plasmid DNAs were mixed together in a $1: 1$ concentration ratio to the maximum amount of DNA required for optimal transfection efficiency. Transfec- 
tions were performed using the Superfect transfection kit. In general, $\sim 25-33 \%$ transfection efficiency was attained with the method used in these experiments. Cells were determined to be transfected if they exhibited $\mathrm{Ca}^{2+}$ responses to the appropriate receptor-specific agonists. Transiently transfected cells displayed the normal pharmacological properties of stably transfected cells.

$\mathrm{Ca}^{2+}$ imaging. The $\mathrm{Ca}^{2+}$-sensitive fluorophore fura-2 (Molecular Probes, Eugene, OR) was used for measuring $\left[\mathrm{Ca}^{2+}\right]_{\mathrm{i}}$ by ratiometric imaging in both dorsal spinal cultures or $1321 \mathrm{~N} 1$ cells. All fluorescence measurements were made from subconfluent areas of the dishes so that individual astrocytes or astrocytoma cells could be readily identified. Single dorsal spinal astrocytes were identified using criteria described by Salter and Hicks (1994). Just before recording, cells were incubated at room temperature for $90 \mathrm{~min}$ (cultured cells) or $60 \mathrm{~min}$ ( $1321 \mathrm{~N} 1 \mathrm{cells})$ in extracellular recording solution composed of $\mathrm{NaCl}, 140 \mathrm{~mm}$; $\mathrm{KCl}, 5.4$ $\mathrm{mm}$; $\mathrm{CaCl}_{2}, 1.3 \mathrm{~mm}$; HEPES, $10 \mathrm{~mm}$; glucose, $33 \mathrm{~mm}$; and tetrodotoxin, $0.5 \mu \mathrm{M}, \mathrm{pH} 7.35$, osmolarity 315-320 mOsm, which had been supplemented with bovine serum albumin (BSA, $0.5 \%)$ and fura-2 AM ( $2 \mu \mathrm{M})$. Subsequently, the culture dish was thoroughly rinsed with extracellular solution lacking fura-2 AM and BSA and was mounted on an inverted microscope (Diaphot-TMD; Nikon). To avoid neuron-astrocyte signaling in dorsal spinal cord cultures, the areas chosen were free from neurons. When required, cultured cells were bathed in extracellular solution with no added $\mathrm{Ca}^{2+}$ and supplemented with $100 \mu \mathrm{M}$ EGTA, referred to as $\mathrm{Ca}^{2+}$-free extracellular solution. Cultures were viewed using a $40 \times \mathrm{CF}$ epifluorescence Fluor objective lens. Recordings were made at room temperature $\left(20-22^{\circ} \mathrm{C}\right)$.

Recording of $\mathrm{Ca}^{2+}$ waves was done by ratiometric imaging. Excitation light at 340 and $380 \mathrm{~nm}$ was generated by a xenon arc lamp and passed through a high-speed, computer-controlled, variable-wavelength monochromator. This light was transmitted to the recording dish via a fiberoptic cable. Emitted light was directed through a $510 \mathrm{~nm}$ bandpass filter and was detected by an intensified CCD camera. The CCD camera black level was set to $>1 \%$ to maximize the dynamic range of the instrument. Images were acquired by computer at a rate of $\sim 2.5 / \mathrm{sec}$ and were stored on a hard disk. Hardware and software for imaging were from Photon Technology International (Lawrenceville, NJ).

Image data were analyzed off-line. The first image in each image set was used as a template for designating each cell as a region of interest within the image. Each $340 \mathrm{~nm}$ image was divided, on a pixel-by-pixel basis, by the corresponding $380 \mathrm{~nm}$ image, producing a ratio image. Averaged values of the ratios within each region of interest were plotted as a function of time. No attempt was made to convert ratio data from images to $\left[\mathrm{Ca}^{2+}\right]_{\mathrm{i}}$.

Drug application. P2YR agonists were dissolved in extracellular solution. Agonists were applied to fields of astrocytoma cells by pressure ejection from a pipette located $\sim 50-70 \mu \mathrm{m}$ from the nearest cell to avoid pressure-induced stretching of cell membranes. All other drugs were dissolved in extracellular solution and were applied directly in the bath.

Measurement of latency of responses to exogenous ATP or ADP. When determining the latency of the responses of individual cells to applications of ATP or ADP, these agonists were applied from a micropipette, the tip of which was a fixed distance $(70 \mu \mathrm{m})$ from each cell. ATP or ADP was applied continuously until a peak increase in $\left[\mathrm{Ca}^{2+}\right]_{i}$ was reached or to a maximum of $60 \mathrm{sec}$. We measured the time $\left(t_{1 / 2}\right)$ from the onset of drug application to the time the $\mathrm{Ca}^{2+}$ response in the stimulated cell reached $50 \%$ of its peak.

Stimulation of $\mathrm{Ca}^{2+}$ waves. $\mathrm{Ca}^{2+}$ waves were evoked by mechanical stimulation of an individual astrocyte or $1321 \mathrm{~N} 1$ cell. A single cell was briefly touched under visual control with the tip (3-5 $\mu$ m diameter) of a fire-polished glass pipette lowered gradually from a height of $\sim 3 \mu \mathrm{m}$ above the cell. The mechanical stimulation was done regularly at $10 \mathrm{~min}$ intervals. Pharmacological manipulations were only performed in cases in which two or more $\mathrm{Ca}^{2+}$ waves were reliably evoked beforehand.

Analysis of data. To determine the rate of $\mathrm{Ca}^{2+}$ wave propagation in P2Y1-1321N1 cells, P2Y2-1321N1 cells, and dorsal spinal cultures, for each cell engaged by the $\mathrm{Ca}^{2+}$ wave, the distance, in micrometers, between the stimulated and target cells was measured and divided by the interval between the onset of the elevation in $\left[\mathrm{Ca}^{2+}\right]_{\mathrm{i}}$ in the stimulated cell and the onset of the elevation in $\left[\mathrm{Ca}^{2+}\right]_{\mathrm{i}}$ in the responding cell, giving a value expressed as micrometers per second. Statistical analysis was performed on grouped data from the total number of cells from each experimental group using an independent $t$ test; $p<0.05$ was considered to indicate a statistically significant difference.

Analysis of pharmacological data. Concentration inhibition data were collected for suramin and pyridoxalphosphate-6-azophenyl-2', $4^{\prime}$ disulfonic acid (PPADS) in P2Y1-1321N1, P2Y2-1321N1, and spinal astrocytes. Inhibition curves were constructed by fitting the mean response amplitude at each concentration with the equation $E=E_{0} /(1+$ $\left.\left([\text { antagonist }] /\left[\mathrm{IC}_{50}\right]\right)^{\mathrm{n}}\right)$, where $E_{0}$ was the response amplitude in the absence of antagonist.

Source of reagents. $2 \mathrm{meSADP}, \mathrm{ADP}$, and UTP were from Research Biochemicals (Natick, MA). Apyrase (grade III) and all other reagents, except where indicated above, were from Sigma. We confirmed that the apyrase was active by using a luciferin-luciferase assay.

\section{Results \\ P2Y2 mediates UTP-evoked $\mathrm{Ca}^{2+}$ responses in spinal astrocytes}

Because the pharmacological profile of UTP-activated $\mathrm{Ca}^{2+}$ responses in spinal dorsal astrocytes (Ho et al., 1995) was reported to be distinct from the profiles that have been described for the three cloned P2YR subtypes activated by UTP, P2Y2, P2Y4, and P2Y6 (Charlton et al., 1996; King et al., 1998), we screened for the potential expression of novel UTP-activated receptors by these astrocytes by using nested RT-PCR to amplify poly $\left(\mathrm{A}^{+}\right)$RNA from dorsal spinal cultures. We used degenerate primers to highly conserved regions in P2Y2, P2Y4, and P2Y6; two downstream primers were made to regions encoding the fifth and the sixth transmembrane domains, and a single upstream primer was made to a region of the third transmembrane domain that is conserved in P2Y2, P2Y4, and P2Y6 as well as in the other known rat P2YRs. This strategy yielded only two products (Fig. 1a, top), which, when sequenced, were found to correspond to a $203 \mathrm{bp}$ fragment of P2Y2 and a $314 \mathrm{bp}$ fragment of P2Y4. The size of the P2Y2 fragment was 108 bp smaller than predicted, likely because of formation of a cDNA hairpin loop (see Fig. 1 legend). Separate RT-PCR with P2Y2-specific primers (Fig. 1a, bottom) confirmed the expression of mRNA for P2Y2.

Because we found no evidence for expression of P2Y6 or of potentially novel UTP-activated P2YRs, and because the previously reported pharmacological characterization of recombinant UTP-activated receptors was done using the human P2Y homologs (Charlton et al., 1996), which show $\sim 89 \%$ sequence identity with rat P2Y2Rs and P2Y4Rs, we wondered whether $\mathrm{Ca}^{2+}$ responses mediated by P2Y2Rs or P2Y4Rs from rat might have pharmacological properties, not previously recognized, that would match the properties of UTP-activated $\mathrm{Ca}^{2+}$ responses in spinal astrocytes. The potentially distinguishing pharmacological properties of UTP-evoked responses in astrocytes (Ho et al., 1995) were blockade by suramin and PPADS. Therefore we compared the effects of suramin and PPADS on responses to UTP in spinal astrocytes versus UTP-evoked responses mediated by recombinant rat P2Y2Rs and rat P2Y4Rs expressed in $1321 \mathrm{~N} 1$ cells, an astrocytoma cell line that lacks endogenous purinoceptors (Parr et al., 1994). Brief, localized applications of UTP (100 $\mu \mathrm{M}$, $1-5 \mathrm{sec}$ ) evoked reproducible $\mathrm{Ca}^{2+}$ responses characterized by a transient rise in $\left[\mathrm{Ca}^{2+}\right]_{\mathrm{i}}$ in individual astrocytes (Fig. 1b) or 1321N1 cells expressing P2Y2Rs (Fig. 1c) or P2Y4Rs (Fig. 1d). These $\mathrm{Ca}^{2+}$ responses were unaffected by removing extracellular $\mathrm{Ca}^{2+}$ (data not shown), indicating that the responses were mediated by release of $\mathrm{Ca}^{2+}$ from intracellular stores.

UTP-evoked responses of dorsal spinal astrocytes showed a 


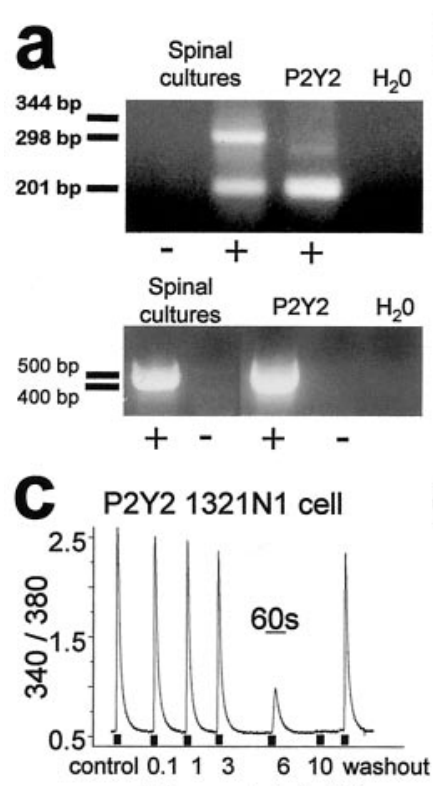

[Suramin] $(\mu \mathrm{M})$

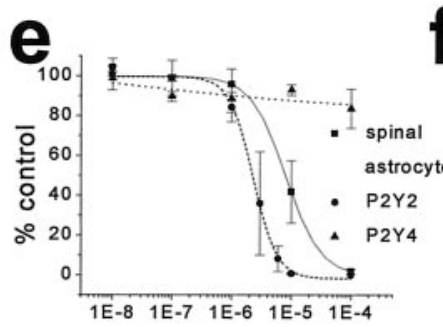

[Suramin] (M)

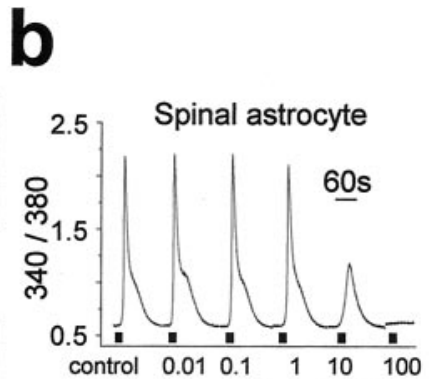

[Suramin] $(\mu \mathrm{M})$



[Suramin] $(\mu \mathrm{M})$
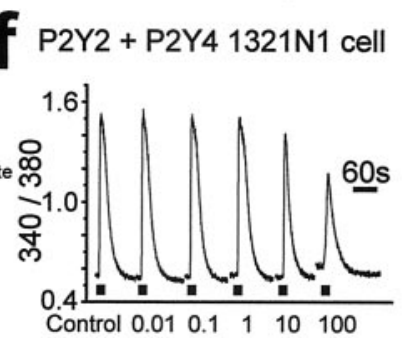

[Suramin] $(\mu \mathrm{M})$
Figure 1. Spinal astrocytes functionally express P2Y2 but not P2Y4. $a$, Top, Result of nested PCR of CDNA from spinal cord cultures and 1321N1 cells expressing P2Y2 using degenerate oligonucleotide primers. +, The template CDNA was generated from an RT reaction, which included the enzyme reverse transcriptase; - , the template for the PCR was taken from a control RT reaction in which no reverse transcriptase was added. Two bands of 314 and $203 \mathrm{bp}$ were detected, which corresponded to P2Y4 and a fragment of P2Y2. The P2Y2R fragment was 108 bp shorter than the expected size based on the published sequence. In other experiments, when $5 \%$ DMSO was included in the PCR mixture, we obtained the full-length of the P2Y2 fragment (Varadaraj and Skinner, 1994) (data not shown). Bottom, Using specific primers, a separate P2Y2 fragment was amplified from spinal cord cultures. This suggested that under the $\mathrm{PCR}$ conditions for the experiments shown in $a, \mathrm{P} 2 \mathrm{Y} 2$ cDNA likely forms a hairpin loop, which is skipped by the DNA polymerase. $b-d, f$, Traces of $340 / 380$ fura- 2 emission ratios; each trace is from an individual cell. Recordings were from a spinal astrocyte $(b)$ or from 1321N1 cells transfected with P2Y2 (c), P2Y4 (d), or P2Y2 and P2Y4 ( $f$ ). The short bars below each trace indicate the periods of application of UTP $(10 \mu \mathrm{M})$. Cells were tested with an ascending series of concentrations of bath-applied suramin; the concentration is indicated below each application of UTP. e, Suramin concentration-inhibition curves of UTP-evoked responses of spinal astrocytes and 1321N1 cells expressing either P2Y2 or P2Y 4 receptors. Each curve is the best fit of the means to the logistic equation $100 /\left(1+\left([\text { suramin }] / \mathcal{C C}_{50}\right)^{\text {slope }}\right)$. The calculated $\mathrm{IC}_{50}$ for suramin at spinal astrocytes was $7 \pm 1 \mu \mathrm{m}(n=5$ cells), and at 1321N1 cells expressing P2Y2 receptors, it was $23 \pm 9 \mu \mathrm{M}(n=5$ cells). For 1321N1 cells expressing P2Y4 receptors, suramin was ineffective ( $n=4$ cells).

concentration-dependent blockade by suramin (Fig. $1 b, e ; n=5$ cells), as did $\mathrm{Ca}^{2+}$ responses mediated by rat P2Y2Rs (Fig. $1 c, e$; $n=5$ cells). On the other hand, $\mathrm{Ca}^{2+}$ responses mediated by rat P2Y4Rs were not significantly suppressed by suramin at concentrations up to $100 \mu \mathrm{M}$ (Fig. $1 d, e ; n=4$ cells). The resistance of responses mediated by $\mathrm{P} 2 \mathrm{Y} 4 \mathrm{R} s$ to suramin implies that P2Y4Rs alone could not account for the UTP-stimulated $\mathrm{Ca}^{2+}$ responses in the astrocytes. To examine whether coexpression of rat P2Y2Rs
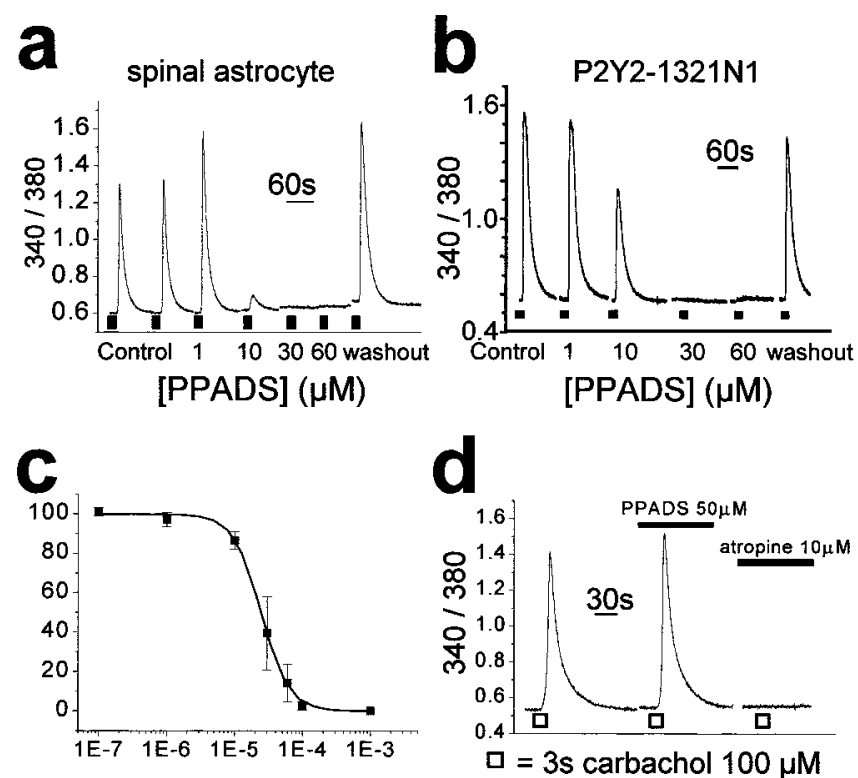

Figure 2. PPADS blocks both the $\mathrm{Ca}^{2+}$ responses of P2Y2-1321N1 cells and spinal astrocytes to UTP but not to carbachol. $a, b$, Representative traces of $340 / 380$ fura-2 emission ratios from a single P2Y2-1321N1 cell and from a dorsal spinal astrocyte evoked by $10 \mu \mathrm{m}$ UTP in the presence of increasing concentrations of PPADS. $c$, Concentration-inhibition curve for PPADS at P2Y2Rs. The curve is the logistic equation best fitted to the means. The calculated IC ${ }_{50}$ for PPADS at the P2Y2 receptor was $24 \pm 0.7 \mu \mathrm{m}$ ( $n=10$ cells). $d$, Untransfected 1321N1 cells were challenged with exogenously applied carbachol $(100 \mu \mathrm{M})$, stimulating endogenous muscarinic acetylcholine receptors. Responses to carbachol were unaffected by PPADS but were blocked by the muscarinic receptor antagonist atropine $(10 \mu \mathrm{m})$.

and rat $\mathrm{P} 2 \mathrm{Y} 4 \mathrm{R}$ s might produce $\mathrm{UTP}$-evoked $\mathrm{Ca}^{2+}$ responses that are sensitive to suramin, for example, by potential heteromultimerization of P2Y2Rs and P2Y4Rs, we coexpressed these receptors in $1321 \mathrm{~N} 1$ cells. We found that the $\mathrm{Ca}^{2+}$ responses activated by UTP were depressed in suramin in a concentration-dependent manner (Fig. $1 f ; n=5$ cells), but even at the highest concentration of suramin tested $(100 \mu \mathrm{M})$, there was a large residual $\mathrm{Ca}^{2+}$ response, with an amplitude approximately half that of the control responses. Thus, with cells coexpressing P2Y2Rs and P2Y4Rs there was a suramin-resistant component that was not seen with the UTP-evoked $\mathrm{Ca}^{2+}$ responses of the spinal astrocytes. Therefore, the $\mathrm{Ca}^{2+}$ responses to UTP in the astrocytes could not be accounted for by expression of P2Y4Rs either alone or together with P2Y2Rs. Furthermore, these results indicated that there is no functional expression of P2Y4Rs by dorsal spinal astrocytes.

These results suggest that $\mathrm{Ca}^{2+}$ responses stimulated by UTP in spinal astrocytes might be mediated by P2Y2Rs. In astrocytes, the UTP-evoked $\mathrm{Ca}^{2+}$ responses show concentration-dependent blockade by PPADS (Fig. 2a) (Ho et al., 1995). However, PPADS is reported to have no effect on responses mediated by human P2Y2Rs (Charlton et al., 1996) in a study that examined the effect of PPADS on phospholipase $\mathrm{C}$ activation. Presently, we examined the effect of PPADS on $\mathrm{Ca}^{2+}$ responses mediated by rat $\mathrm{P} 2 \mathrm{Y} 2 \mathrm{Rs}$ stably transfected into $1321 \mathrm{~N} 1$ cells (P2Y2-1321N1 cells). We found that the $\mathrm{Ca}^{2+}$ responses evoked by UTP $(10 \mu \mathrm{M})$ in P2Y2-1321N1 cells were blocked by bath applying PPADS (Fig. $2 b$ ). The blockade by PPADS was concentration-dependent, with an $\mathrm{IC}_{50}$ of $24 \pm 0.7 \mu \mathrm{M}(n=10$ cells; Fig. $2 c)$. In contrast, PPADS $(50 \mu \mathrm{M})$ had no effect on $\mathrm{Ca}^{2+}$ responses evoked by stimulating muscarinic acetylcholine receptors, which are endogenously expressed in $1321 \mathrm{~N} 1$ cells (Fig. $2 d$ ), indicating that the 
effect of PPADS on P2Y2R-mediated $\mathrm{Ca}^{2+}$ responses was not attributable to a nonspecific action of PPADS on intracellular $\mathrm{Ca}^{2+}$ signaling. Hence, $\mathrm{Ca}^{2+}$ responses mediated by rat $\mathrm{P} 2 \mathrm{Y} 2 \mathrm{Rs}$ expressed heterologously, as well as by the endogenous UTPactivated receptor in spinal astrocytes, are antagonized by PPADS. Thus, from the convergence of our molecular and pharmacological findings, we conclude that the receptor mediating the $\mathrm{Ca}^{2+}$ responses of rat dorsal spinal astrocytes to UTP is the P2Y2R.

\section{$\mathrm{Ca}^{2+}$ wave propagation by native and} recombinant $\mathrm{P} 2 \mathrm{Y} 2$ receptors

In spinal astrocyte networks, $\mathrm{Ca}^{2+}$ wave propagation is suppressed by the selective $\mathrm{P} 2 \mathrm{Y} 1$ receptor antagonist $\mathrm{A} 3 \mathrm{P} 5 \mathrm{PS}$, and the blockade of $\mathrm{Ca}^{2+}$ waves that persist in adenosine $3^{\prime}$-phosphate-5' -phosphosulfate (A3P5PS) by suramin imply that the $\mathrm{Ca}^{2+}$ waves require activation of a subtype of P2YR in addition to P2Y1 (Fam et al., 2000). In the present study, we found that suramin discriminates between the two non-P2Y1R subtypes for which mRNA was detected: suramin blocks $\mathrm{Ca}^{2+}$ responses mediated by P2Y2Rs, but those mediated by P2Y4Rs are resistant to suramin (Fig. 1). These findings imply that, in the spinal astrocyte network, P2Y2R activation mediates the component of the $\mathrm{Ca}^{2+}$ wave that is not propagated via P2Y1Rs.

To determine whether P2Y2Rs are sufficient to support $\mathrm{Ca}^{2+}$ waves, we investigated responses of P2Y2-1321N1 cells to singlecell mechanical stimulation, which in spinal astrocytes initiates $\mathrm{Ca}^{2+}$ waves (Fam et al., 2000). In P2Y2-1321N1 cells, mechanical stimulation of one cell resulted in a rise in $\left[\mathrm{Ca}^{2+}\right]_{\mathrm{i}}$ in that cell, which was followed by a wave of increased $\left[\mathrm{Ca}^{2+}\right]_{\mathrm{i}}$ that spread concentrically to cells throughout the field (Fig. 3). In nontransfected $1321 \mathrm{~N} 1$ cells, mechanical stimulation increased $\left[\mathrm{Ca}^{2+}\right]_{\mathrm{i}}$ in the stimulated cell; however, there was no change in $\left[\mathrm{Ca}^{2+}\right]_{\mathrm{i}}$ in neighboring cells (Fam et al., 2000). Moreover, the spread of the $\mathrm{Ca}^{2+}$ waves in P2Y2-1321N1 cells was prevented by bath applying suramin.

To determine whether expression of $\mathrm{P} 2 \mathrm{Y} 2 \mathrm{Rs}$ permits the spread, as opposed to the initiation, of the $\mathrm{Ca}^{2+}$ waves, we transiently transfected $1321 \mathrm{~N} 1$ cells with P2Y2Rs so that transfected and nontransfected cells were intermingled. The transfection conditions were set such that only approximately one-quarter of the cells expressed functional P2Y2Rs, as indicated by rapid $\mathrm{Ca}^{2+}$ responses of these cells to focal application of UTP (50 $\mu \mathrm{M}, 2$ sec duration; Fig. 3). We found that mechanically stimulating an individual cell evoked a $\mathrm{Ca}^{2+}$ wave that spread only to those cells that responded to UTP (58 cells in nine fields); the $\mathrm{Ca}^{2+}$ wave did not engage cells that did not respond to UTP. Mechanical stimulation of cells responsive to UTP initiated $\mathrm{Ca}^{2+}$ waves, as did stimulation of cells that were themselves unresponsive to UTP (Fig. 3). Thus, $\mathrm{Ca}^{2+}$ waves were initiated by mechanical stimulation regardless of whether the stimulated cell itself did or did not express P2Y2Rs. These findings imply that expression of P2Y2Rs is sufficient to permit the spread of $\mathrm{Ca}^{2+}$ waves in cells that normally do not express this receptor, but $\mathrm{P} 2 \mathrm{Y} 2 \mathrm{R}$ expression is not required for the initiation of $\mathrm{Ca}^{2+}$ waves. Taking these results together, we conclude that in the spinal astrocyte network, a component of $\mathrm{Ca}^{2+}$ waves is mediated by endogenous P2Y2Rs.
Differing rates of propagation of $\mathrm{Ca}^{2+}$ waves mediated by $\mathrm{P} 2 \mathrm{Y} 1$ versus $\mathrm{P} 2 \mathrm{Y} 2$ receptors

In characterizing the properties of $\mathrm{Ca}^{2+}$ waves mediated by P2Y1Rs and P2Y2Rs, we examined the rate at which the $\mathrm{Ca}^{2+}$ waves spread. We measured the time interval between the onset of the $\left[\mathrm{Ca}^{2+}\right]_{\mathrm{i}}$ change in the stimulated cell and the onset of the rise in $\left[\mathrm{Ca}^{2+}\right]_{\mathrm{i}}$ in the target cell. The rate of $\mathrm{Ca}^{2+}$ wave propagation to each individual cell that participated in the $\mathrm{Ca}^{2+}$ wave was then calculated by dividing the distance between the target cell and the stimulated cell by the measured time interval. In the spinal astrocyte network, where both P2Y1Rs and P2Y2Rs are expressed, we found that the mean rate of $\mathrm{Ca}^{2+}$ wave propagation was $19.4 \pm 0.8 \mu \mathrm{m} / \mathrm{sec}(n=149$ cells in 23 fields). To determine separately the rate of spread of $\mathrm{Ca}^{2+}$ waves mediated by the individual subtypes of P2YRs, we used cell lines stably expressing P2Y1 (P2Y1-1321N1) or P2Y2 (P2Y2-1321N1) receptors. In $\mathrm{P} 2 \mathrm{Y} 1-1321 \mathrm{~N} 1$ cells, the mean rate of $\mathrm{Ca}^{2+}$ wave propagation was found to be $7.6 \pm 0.3 \mu \mathrm{m} / \mathrm{sec}(n=201$ cells in 21 fields). In contrast, in P2Y2-1321N1 cells, the mean rate of propagation was $17.1 \pm 0.7 \mu \mathrm{m} / \mathrm{sec}(n=175$ cells in 19 fields; Fig. 4$)$, which was significantly greater than the rate in P2Y1-1321N1 cells $(p<$ 0.0001 , Student's $t$ test).

A possible explanation for the difference in the rates of $\mathrm{Ca}^{2+}$ wave propagation between $\mathrm{P} 2 \mathrm{Y} 1-1321 \mathrm{~N} 1$ and $\mathrm{P} 2 \mathrm{Y} 2-1321 \mathrm{~N} 1$ cells was clonal variation in the cell lines expressing the receptors. We investigated this possibility by measuring the rates of $\mathrm{Ca}^{2+}$ wave propagation in $1321 \mathrm{~N} 1$ cells transiently expressing $\mathrm{P} 2 \mathrm{Y} 1$ or $\mathrm{P} 2 \mathrm{Y} 2$ so that there was no clonal selection. We found that in cells in which P2Y1 was transiently expressed, the mean rate of $\mathrm{Ca}^{2+}$ wave propagation was $5.9 \pm 0.7 \mu \mathrm{m} / \mathrm{sec}(n=20$ cells from six fields from three separate transfections). In cells transiently expressing P2Y2Rs, the mean rate of $\mathrm{Ca}^{2+}$ wave propagation was $15.6 \pm 0.9 \mu \mathrm{m} / \mathrm{sec}(n=58$ cells from nine fields from three separate transfections), which was significantly faster than the rate of $\mathrm{Ca}^{2+}$ wave propagation with transient expression of P2Y1Rs $(p<0.0001)$. The rate of propagation of $\mathrm{Ca}^{2+}$ waves through the cells transiently transfected with P2Y1 was not significantly different from the rate in the stable cell line $(p=0.11)$. Similarly, the rate of propagation of the $\mathrm{Ca}^{2+}$ wave through cells transiently expressing P2Y2Rs was not different from the rate of propagation through $\mathrm{P} 2 \mathrm{Y} 2-1321 \mathrm{~N} 1$ cells $(p=0.23)$. Thus, clonal variation cannot account for the difference in the rate of 

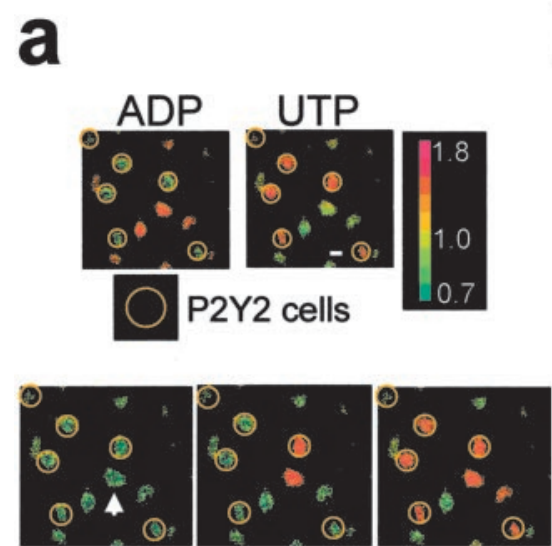

b

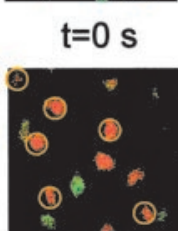

$15 \mathrm{~s}$
$5 \mathrm{~s}$

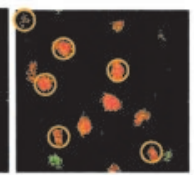

$20 \mathrm{~s}$


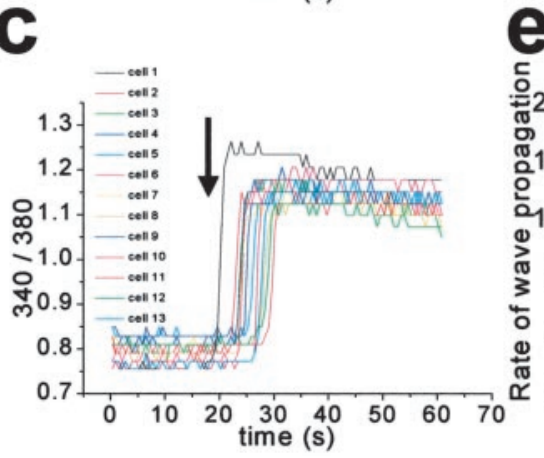

Figure 4. $\quad \mathrm{Ca}^{2+}$ waves propagate at a greater rate in P2Y2-1321N1 cells than in P2Y1-1321N1 cells. a, Representative example of a $\mathrm{Ca}^{2+}$ wave in a field in which P2Y1-1321N1 cells were mixed with P2Y2-1321N1 cells. P2Y1-1321N1 cells were identified by observing $\left[\mathrm{Ca}^{2+}\right]_{\mathrm{i}}$ after application of 2meSADP (5 $\left.\mu \mathrm{M}\right)$, whereas P2Y2-1321N1 cells were identified by focal application of UTP (50 $\mu \mathrm{M})$. No cells responded to both agonists. Cells that responded to UTP are circled in yellow. $\mathrm{A} \mathrm{Ca}^{2+}$ wave was stimulated by touching the cell labeled with the arrow. The subsequent panels show the spread of the $\mathrm{Ca}^{2+}$ wave at 5, 10,15, and 20 sec after stimulation. $b$, $c$, Representative traces of the 340/380 fura- 2 emission ratios in two separate fields of cells after stimulation of cell 1 in each field at the time indicated by the arrow. P2Y1-1321N1 cells are shown in $b ; \mathrm{P} 2 \mathrm{Y} 2-1321 \mathrm{~N} 1$ cells are shown in $c$. $d$, Histogram illustrating the distribution of the rates of $\mathrm{Ca}^{2+}$ wave propagation in P2Y1-1321N1 and P2Y2-1321N1 cells. The calculated rates of $\mathrm{Ca}^{2+}$ wave propagation in P2Y1-1321N1 and P2Y2-1321N1 were grouped in 1 sec bins. Each bin represents the number of cells to which $\mathrm{Ca}^{2+}$ waves propagated at that particular speed. $e$, Mean rate of $\mathrm{Ca}^{2+}$ wave propagation in P2Y1-1321N1 cells compared with the mean rate of $\mathrm{Ca}^{2+}$ wave propagation in P2Y2-1321N1 cells ( $p<0.001 ; n=210$ cells in 21 fields of P2Y1-1321N1 cells and $n=175$ cells in 19 fields of P2Y2-1321N1 cells).

propagation of $\mathrm{Ca}^{2+}$ waves in $\mathrm{P} 2 \mathrm{Y} 1-1321 \mathrm{~N} 1$ versus $\mathrm{P} 2 \mathrm{Y} 2-$ $1321 \mathrm{~N} 1$ cells. Hence, with either transient or stable expression of the receptors, $\mathrm{Ca}^{2+}$ waves mediated by $\mathrm{P} 2 \mathrm{Y} 2 \mathrm{Rs}$ propagate more rapidly than do those mediated by P2Y1Rs.

P2YR-mediated $\mathrm{Ca}^{2+}$ waves are initiated through release of ATP from the stimulated cell, diffusion of ATP to target cells, and the activation of P2YRs on those cells, leading to downstream release of stored intracellular $\mathrm{Ca}^{2+}$. The difference in the rate of $\mathrm{Ca}^{2+}$ wave propagation between $\mathrm{P} 2 \mathrm{Y} 1$ - and $\mathrm{P} 2 \mathrm{Y} 2$-expressing cell lines might be a result of differences in any of these steps; therefore, we explored each step separately, as described in the following sections.

\section{Difference in rate of $\mathrm{Ca}^{2+}$ wave propagation is independent} of $\mathrm{P} 2 \mathrm{Y}$ receptor expression on the cell initiating the wave It is possible that the rate of $\mathrm{Ca}^{2+}$ wave propagation in P2Y2$1321 \mathrm{~N} 1$ cells was calculated to be faster than that in P2Y1$1321 \mathrm{~N} 1$ cells because the initiation of the waves was more rapid in P2Y2-1321N1 cells. To examine this possibility, we intermingled P2Y1-1321N1 with P2Y2-1321N1 cells and simultaneously recorded P2Y1- and P2Y2-mediated $\mathrm{Ca}^{2+}$ waves initiated by stimulating a single cell expressing either type of receptor. We found that when a cell expressing $\mathrm{P} 2 \mathrm{Y} 1$ was stimulated, the rate of $\mathrm{Ca}^{2+}$ wave propagation to other P2Y1-expressing cells was $7.5 \pm 0.8$ $\mu \mathrm{m} / \mathrm{sec}$, whereas the rate of propagation to P2Y2-expressing cells was $16.3 \pm 1.8 \mu \mathrm{m} / \mathrm{sec}$ ( $n=43$ and 53 cells, respectively, in 12 fields; $p<0.001$ ). Conversely, when a cell expressing P2Y2Rs was stimulated, the rate of $\mathrm{Ca}^{2+}$ wave propagation to $\mathrm{P} 2 \mathrm{Y} 1$ expressing cells was $7.5 \pm 0.9$ versus $16.7 \pm 0.9 \mu \mathrm{m} / \mathrm{sec}$ in $\mathrm{P} 2 \mathrm{Y} 2$ expressing cells ( $n=37$ and 43 cells, respectively, in 10 fields; $p<$
0.001). Thus, regardless of which subtype of P2YR was expressed in the cell from which the $\mathrm{Ca}^{2+}$ wave originated, the rate at which the $\mathrm{Ca}^{2+}$ waves spread in P2Y2-expressing cells was significantly faster than that in P2Y1-expressing cells.

\section{Ectonucleotidase inhibitor ARL 67156 has no effect on $\mathrm{Ca}^{2+}$ wave propagation}

ATP released from a stimulated astrocyte diffuses through the extracellular space to reach and activate P2YRs on surrounding cells. In the extracellular environment, ATP may be hydrolyzed by ectonucleotidases, ubiquitous surface-bound enzymes that metabolize extracellular nucleotides (Zimmermann, 2000). We considered that extracellular hydrolysis may participate in $\mathrm{Ca}^{2+}$ wave propagation because P2Y2Rs are selectively activated by ATP, whereas P2Y1Rs are preferentially activated by ADP (Fig. $5 a$ ) (North and Barnard, 1997). We thus hypothesized that $\mathrm{Ca}^{2+}$ waves mediated via activation of P2Y1Rs may require the conversion of ATP to ADP to activate the receptors, in which case the slower rate of $\mathrm{Ca}^{2+}$ wave propagation to cells expressing P2Y1Rs might be attributable to such an additional enzymatic step.

We therefore examined the effect of ARL 67156, a selective ectonucleotidase inhibitor (Crack et al., 1995; Westfall et al., 1997), on the rate of spread of $\mathrm{Ca}^{2+}$ waves in P2Y1-1321N1 and P2Y2-1321N1 cells. If $\mathrm{Ca}^{2+}$ wave propagation via P2Y1Rs requires that ATP be hydrolyzed to ADP, then inhibiting ectonucleotidase activity would be predicted to prevent $\mathrm{Ca}^{2+}$ waves in P2Y1-1321N1 cells. However, we found that $\mathrm{Ca}^{2+}$ waves persisted in P2Y1-1321N1 cells during bath application of ARL $67156(100 \mu \mathrm{M}$; Fig. $5 b, c)$, at a concentration of ARL that causes $70 \%$ inhibition of ATP dephosphorylation by human red blood 

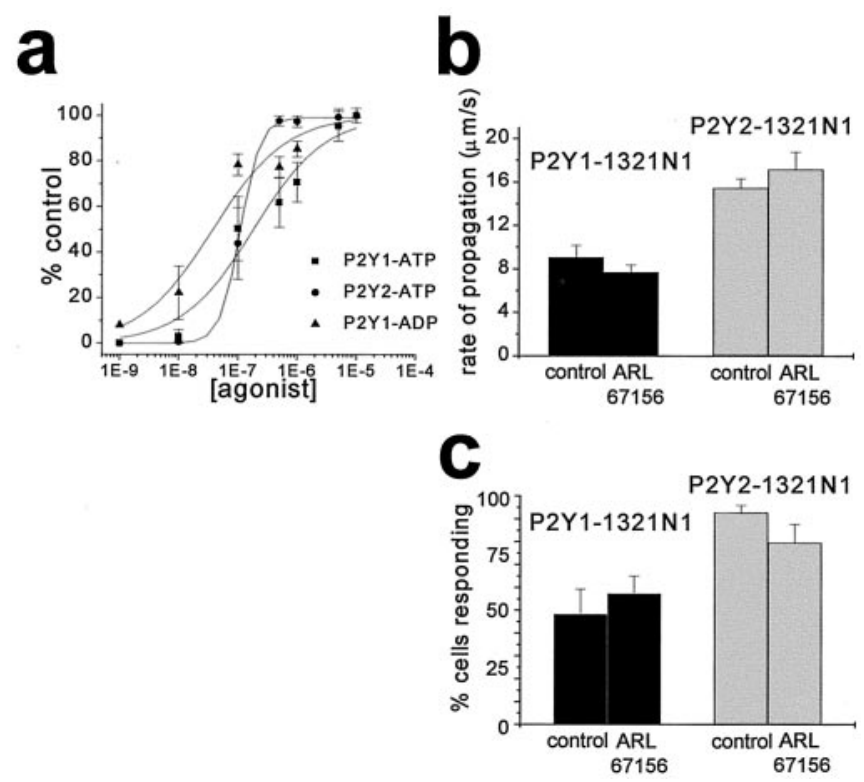

Figure 5. Ectonucleotidase inhibitor ARL 67156 has no effect on $\mathrm{Ca}^{2+}$ wave propagation. a Concentration-response curves for ADP (triangles) and ATP (squares) at P2Y1-1321N1 cells and for ATP (circles) at P2Y2-1321N1 cells. Each data point is the mean \pm SEM of the response to the applied agonist at each concentration for $n=5-10$ cells. Each curve is the best fit of the means to the logistic equation $100 /\left(1+\left(\mathrm{EC}_{50} /[\text { agonist }]\right)^{\text {slope }}\right)$. The calculated $\mathrm{EC}_{50}$ values are as follows: P2Y1-ATP, $183 \pm 53 \mathrm{~nm}$; P2Y1-ADP, $38 \pm 14 \mathrm{~nm}$; P2Y2-ATP, $109 \pm 21$ nм. вecause $A D P$ is more potent than ATP at the P2Y1 receptor, we hypothesized that an ectonucleotidase was required to metabolize ATP to ATP for P2Y1-expressing cells to be engaged by the $\mathrm{Ca}^{2+}$ wave. $b$, Comparison of the rates of $\mathrm{Ca}^{2+}$ wave propagation in intermingled P2Y1-1321N1 and P2Y2-1321N1 cells before and during incubation with the ectonucleotidase inhibitor ARL 67156 ( $n=12$ fields). c, Comparison of the percentages of P2Y1-1321N1 and P2Y2-1321N1 cells that are engaged by the $\mathrm{Ca}^{2+}$ wave before and during incubation with ARL $67156(n=12$ fields).

cells (Crack et al., 1995). In the presence of ARL 67156, the rate of $\mathrm{Ca}^{2+}$ wave propagation in P2Y1-expressing cells was $7.7 \pm 0.7$ $\mu \mathrm{m} / \mathrm{sec}$ versus the control rate of $9.1 \pm 1.1 \mu \mathrm{m} / \mathrm{sec}(n=37$ cells in 12 fields; $p>0.5$ ). ARL 67156 also had no effect on the rate of $\mathrm{Ca}^{2+}$ wave propagation in P2Y2-1321N1 cells: in ARL 67156, the rate was $17.1 \pm 1.5 \mu \mathrm{m} / \mathrm{sec}$ versus the control rate of $15.4 \pm 0.9$ $\mu \mathrm{m} / \mathrm{sec}(n=49$ cells in 12 fields; $p>0.5)$. Thus, we find no evidence that ectonucleotidase activity participates in or regulates the rate of propagation of $\mathrm{Ca}^{2+}$ waves mediated by P2Y1Rs or P2Y2Rs expressed in $1321 \mathrm{~N} 1$ cells.

\section{ATP-evoked $\mathrm{Ca}^{2+}$ responses mediated by $\mathrm{P} 2 \mathrm{Y} 1$ receptors are generated more slowly than those mediated by P2Y2 receptors}

Because there was no evidence for extracellular conversion of ATP to ADP, P2Y1Rs and P2Y2Rs may be exposed to comparable concentrations of ATP during the passage of a $\mathrm{Ca}^{2+}$ wave. Thus, the remaining potential explanation for the faster rate of $\mathrm{Ca}^{2+}$ wave propagation via $\mathrm{P} 2 \mathrm{Y} 2 \mathrm{Rs}$ is that these receptors may transduce the extracellular ATP signal into a change in $\left[\mathrm{Ca}^{2+}\right]_{\mathrm{i}}$ more rapidly than do $\mathrm{P} 2 \mathrm{Y} 1 \mathrm{Rs}$. Therefore, we examined the time course of $\mathrm{Ca}^{2+}$ responses to ATP $(0.1-10 \mu \mathrm{M})$ applied by pressure ejection directly onto individual cells expressing either P2Y1Rs or P2Y2Rs. ATP was applied continuously until the rise in $\left[\mathrm{Ca}^{2+}\right]_{\mathrm{i}}$ had peaked, and we measured the time from the start of the application to when $\left[\mathrm{Ca}^{2+}\right]_{\mathrm{i}}$ reached half of the peak value $\left(t_{1 / 2}\right)$.

We found that $t_{1 / 2}$ decreased with increasing concentrations of ATP for $\mathrm{Ca}^{2+}$ responses mediated by P2Y1Rs or P2Y2Rs. For
$100 \mathrm{~nm}$ ATP, $t_{1 / 2}$ for P2Y1R-mediated responses was not different from that of P2Y2R-mediated responses; however, at all higher concentrations of ATP tested, we found that $t_{1 / 2}$ for P2Y1Rmediated $\mathrm{Ca}^{2+}$ responses was significantly longer than that for P2Y2R-mediated responses (Fig. 6a,b,d). Thus, at ATP concentrations $>100 \mathrm{~nm}, \mathrm{P} 2 \mathrm{Y} 1 \mathrm{Rs}$ generated $\mathrm{Ca}^{2+}$ responses more slowly than did P2Y2Rs. The difference in $t_{1 / 2}$ persisted even when we accounted for the slight difference in $\mathrm{EC}_{50}$ values for ATP at the two receptors (Fig. $6 d$, inset); thus, the difference in rate of signal transduction at greater than the $\mathrm{EC}_{50}$ values was not attributable to the difference in potency of ATP at P2Y1 versus P2Y2Rs. We wondered whether the slow rate of P2Y1-mediated $\mathrm{Ca}^{2+}$ responses is an intrinsic characteristic of responses mediated by this subtype of P2YR. To address this, we compared $\mathrm{Ca}^{2+}$ responses of P2Y1-1321N1 cells evoked by ADP with those observed when P2Y1-1321N1 cells were stimulated with ATP (Fig. $6 e$ ). As with responses to ATP, the $t_{1 / 2}$ for P2Y1-mediated $\mathrm{Ca}^{2+}$ responses evoked by ADP was inversely related to agonist concentration. However, at each concentration tested, the $t_{1 / 2}$ for responses evoked by $\mathrm{ADP}$ was significantly less than $t_{1 / 2}$ for responses to ATP. ADP is approximately five times more potent at P2Y1Rs than is ATP (Fig. 5a), but even when we corrected for this difference in potency, ADP-evoked responses were faster than were responses to ATP at concentrations above the respective $\mathrm{EC}_{50}$ (Fig. 6e, inset). Thus, the slow rate of signaling of P2Y1Rs when stimulated with ATP is not an inherent characteristic of the receptors themselves because the signaling was much faster when the receptors were stimulated with ADP. Indeed, with ADP stimulation, the $t_{1 / 2}$ values for P2Y1 receptor-mediated $\mathrm{Ca}^{2+}$ responses were comparable with $t_{1 / 2}$ values for P2Y2-mediated $\mathrm{Ca}^{2+}$ responses with ATP stimulation (Fig. $6 c$ ).

These data show that the rate at which P2Y1Rs and P2Y2Rs respond to extracellular nucleotides is both agonist- and concentration-dependent. When P2Y1Rs and P2Y2Rs are stimulated with equal concentrations of ATP, P2Y1Rs are slower to generate a rise in $\left[\mathrm{Ca}^{2+}\right]_{\mathrm{i}}$ than are P2Y2Rs; however, stimulation of P2Y1 with ADP evokes a rapid elevation in $\left[\mathrm{Ca}^{2+}\right]_{\mathrm{i}}$.

Apyrase increases the rate of propagation of $\mathrm{Ca}^{2+}$ waves to P2Y1-expressing cells but prevents the spread of $\mathrm{Ca}^{2+}$ waves to P2Y2-expressing cells

Taking the results above together, we infer that the spread of $\mathrm{Ca}^{2+}$ waves mediated via activation of P2Y1Rs is slower than that via $\mathrm{P} 2 \mathrm{Y} 2 \mathrm{Rs}$ primarily because $\mathrm{P} 2 \mathrm{Y} 1 \mathrm{Rs}$ transduce extracellular ATP signals more slowly than do P2Y2Rs. Nevertheless, because P2Y1R-mediated $\mathrm{Ca}^{2+}$ responses were rapid when the receptors were activated by ADP (see above), we predicted that the rate of $\mathrm{Ca}^{2+}$ wave propagation between P2Y1-expressing cells should increase if the waves were to propagate using ADP instead of ATP as the extracellular messenger. To test this prediction, we facilitated the extracellular conversion of ATP to ADP by bath applying the nucleotidase apyrase. For this, we used a grade of apyrase that contains predominantly ATPase activity with lesser ADPase activity and only trace AMPase activity (grade III apyrase; Sigma) to minimize degradation of ADP but enhance hydrolysis of ATP.

For these experiments, P2Y1-1321N1 cells were intermingled with P2Y2-1321N1 cells. We found that during bath application of apyrase $(30 \mathrm{U} / \mathrm{ml})$, the rate of $\mathrm{Ca}^{2+}$ wave propagation in $\mathrm{P} 2 \mathrm{Y} 1-1321 \mathrm{~N} 1$ cells increased from $8.6 \pm 1.1$ to $21.2 \pm 1.4 \mu \mathrm{m} /$ $\sec (p<0.001 ;$ Fig. $7 a-c, e)$. In addition, the proportion of $\mathrm{P} 2 \mathrm{Y} 1-$ expressing cells that participated in the $\mathrm{Ca}^{2+}$ waves increased from $36 \%$ of the cells per field under control conditions to $77 \%$ of the cells during apyrase application (control, $n=19$ cells; 

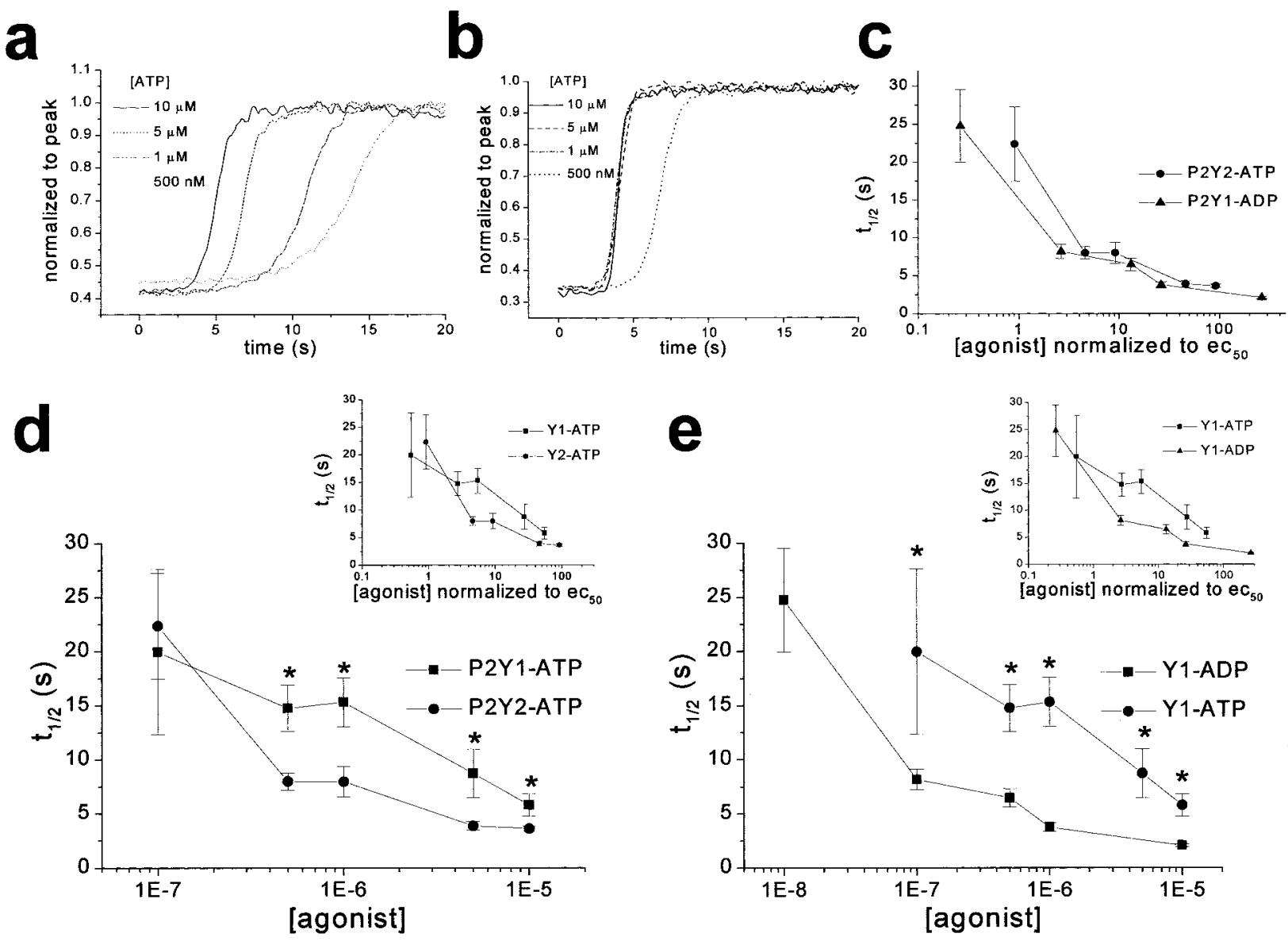

Figure 6. P2Y1-expressing cells take longer to generate an elevation in $\left[\mathrm{Ca}^{2+}\right]_{\mathrm{i}}$ than P2Y2-expressing cells when stimulated with ATP. ATP or ADP, at varying concentrations, were applied by picospritzer from a fixed distance $(70 \mu \mathrm{m})$ onto single astrocytoma cells expressing either P2Y1 or P2Y2. $a, b$, Representative normalized examples of responses from single P2Y1-1321N1- and P2Y2-1321N1-expressing cells, respectively, when stimulated with ATP at concentrations of 100 and $500 \mathrm{~nm}$ and 1 and $10 \mu \mathrm{m}$. c, Comparison of the time to half-maximal response $\left(t_{1 / 2}\right)$ for ADP at P2Y1-1321N1 cells to that of ATP at P2Y2-1321N1 cells when each $t_{1 / 2}$ is normalized to the appropriate $\mathrm{EC}_{50}$. d, Comparison of the $t_{1 / 2}$ for each concentration of ATP applied to either P2Y1-1321N1 cells (squares) or P2Y2-1321N1 cells (circles). Inset, $t_{1 / 2}$ normalized to the EC ${ }_{50}$ values for ATP at the P2Y1 and P2Y2 receptors. Because ADP is a more potent agonist than ATP at the P2Y1 receptor, we investigated $t_{1 / 2}$ for varying concentrations of ADP applied to P2Y1-1321N1 cells. e, Comparison of the $t_{1 / 2}$ for each concentration of ADP applied to P2Y1-1321N1 cells with the $t_{1 / 2}$ for ATP for the same concentrations of ATP also applied to P2Y1-1321N1 cells. Inset, $t_{1 / 2}$ normalized to the EC ${ }_{50}$ values for ATP and ADP at the P2Y1 receptor.

apyrase, $n=41$ cells in seven fields; Fig. $7 d$ ). As a positive control for the activity of the apyrase, we predicted that the spread of $\mathrm{Ca}^{2+}$ waves in P2Y2-1321N1 cells should be suppressed by the nucleotidase because ADP and AMP are inactive at P2Y2Rs (North and Barnard, 1997). During apyrase application, 5\% of $\mathrm{P} 2 \mathrm{Y} 2$-expressing cells participated in the $\mathrm{Ca}^{2+}$ wave in contrast to $61 \%$ of $\mathrm{P} 2 \mathrm{Y} 2$-expressing cells that participated in the control $\mathrm{Ca}^{2+}$ wave (control wave, $n=22$ cells; apyrase, $n=2$ cells in seven fields; Fig. $7 d$ ). In the presence of apyrase, the rate of $\mathrm{Ca}^{2+}$ wave propagation for the P2Y2-1321N1 cells decreased from 19.4 $\mu \mathrm{m} / \mathrm{sec}$ in the control wave to $8.7 \mu \mathrm{m} / \mathrm{sec}$ for the two cells that were engaged by the wave in apyrase (Fig. 7e).

That apyrase suppresses the number of P2Y2-expressing cells that are engaged by the $\mathrm{Ca}^{2+}$ wave is readily predicted because this nucleotidase degrades extracellular ATP, the chemical intermediary of the waves. The observation that $\mathrm{Ca}^{2+}$ waves mediated by P2Y1Rs are facilitated by apyrase, which may seem paradoxical on the basis that apyrase degrades ATP, is nonetheless also readily predicted on the basis that ADP is a more potent ligand at P2Y1Rs than is ATP and on the basis of our finding, described above, that the speed at which P2Y1Rs generate $\mathrm{Ca}^{2+}$ responses is greater when the receptors are activated by ADP than by ATP. Thus, apyrase can be used to differentiate endogenous responses medi- ated by P2Y2Rs versus P2Y1Rs: it selectively suppresses activation of P2Y2Rs by degrading ATP but maintains activation of P2Y1Rs, presumably by producing ADP.

\section{$\mathrm{Ca}^{2+}$ waves in $1321 \mathrm{~N} 1$ cells coexpressing P2Y1 and P2Y2 receptors}

In spinal cord astrocytes, the majority of cells express both P2Y1Rs and P2Y2Rs (Ho et al., 1995), whereas in the experiments described above, we expressed either P2Y1Rs or P2Y2Rs in individual cells. To determine whether expression of both receptor subtypes in individual cells affects the characteristics of $\mathrm{Ca}^{2+}$ waves, we cotransfected these receptors together into $1321 \mathrm{~N} 1$ cells. In these experiments $\sim 30 \%$ of cells responded to either ADP or UTP. Of these cells, $80 \%$ were found to respond both to ADP and to UTP, indicating that they functionally expressed both P2Y1Rs and P2Y2Rs; $13 \%$ responded only to ADP, whereas $7 \%$ responded to UTP but not ADP. In the $13 \%$ of cells that responded only to ADP the mean rate of $\mathrm{Ca}^{2+}$ wave propagation was $8.1 \pm 1.7 \mu \mathrm{m} / \mathrm{sec}(n=9$ cells $)$, whereas in cells that responded only to UTP, the mean rate was $17.9 \pm 2.7 \mu \mathrm{m} / \mathrm{sec}(n=$ 5 cells). These rates of propagation were significantly different from one another $(p<0.01)$ but were similar to the rates of $\mathrm{Ca}^{2+}$ wave propagation observed in the $1321 \mathrm{~N} 1$ cells that stably ex- 
a
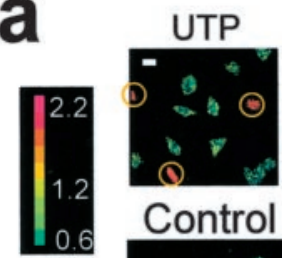

Control
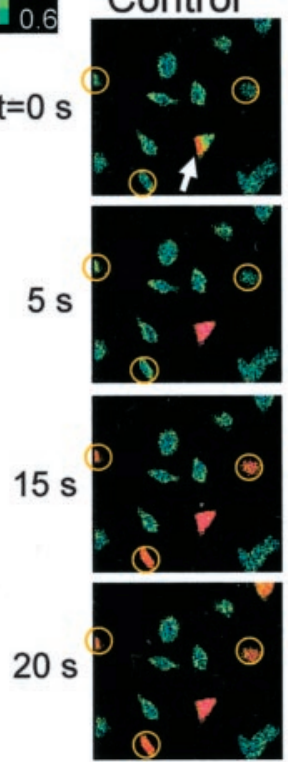



b
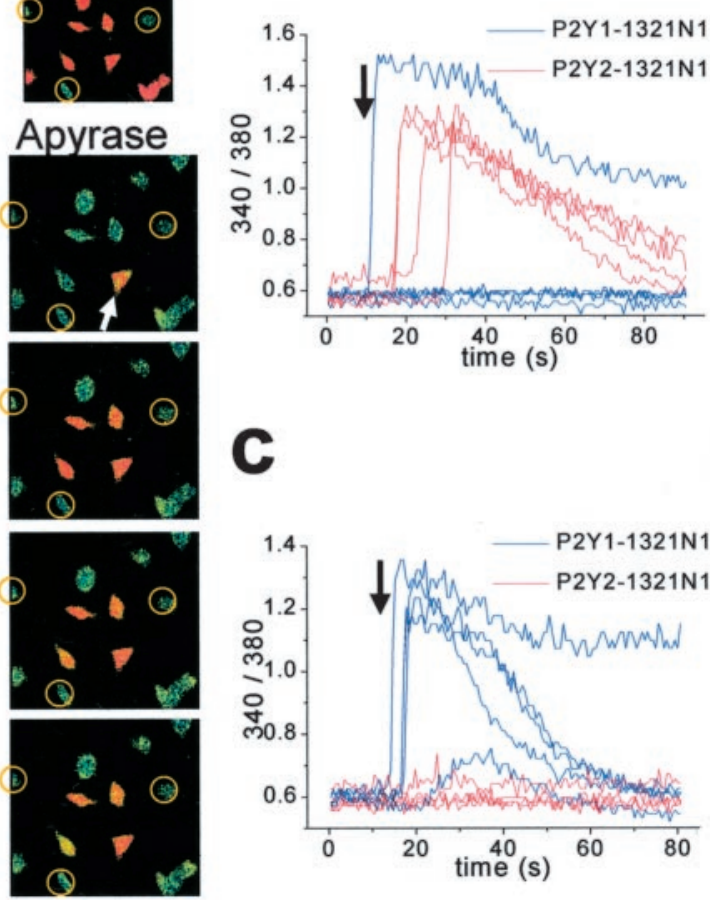
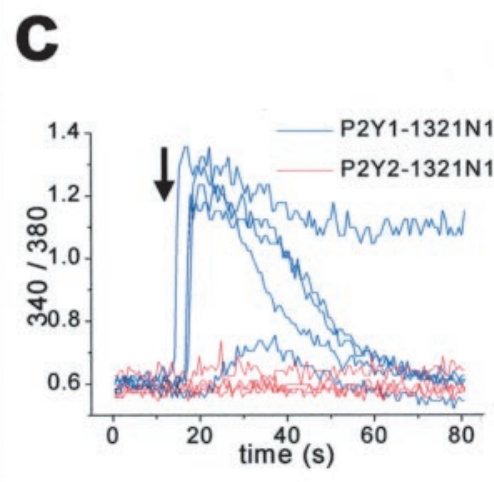
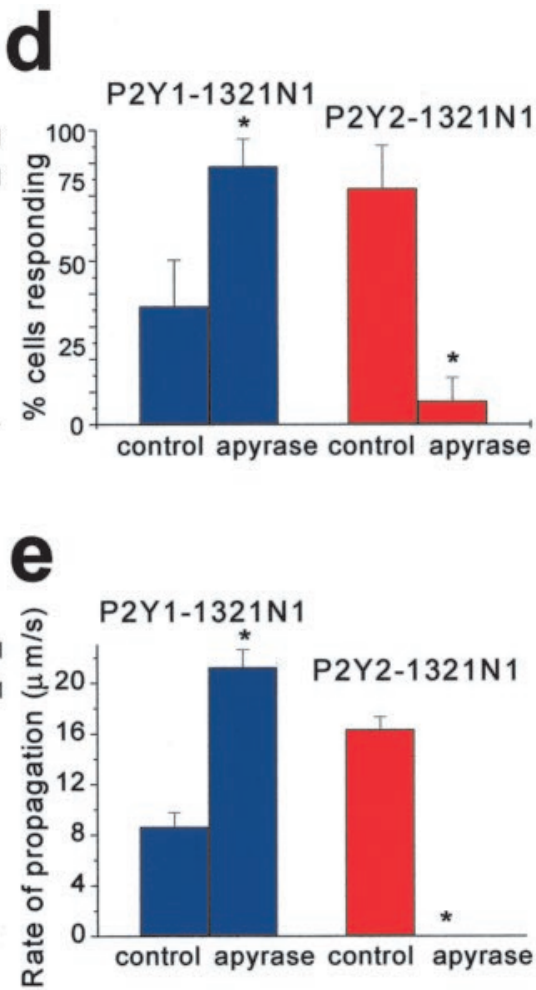

Figure 7. Apyrase blocks $\mathrm{Ca}^{2+}$ wave propagation in P2Y2-1321N1 cells, whereas it increases the rate of Ca ${ }^{2+}$ wave propagation in P2Y1-1321N1 cells. $a$, Field of cells in which cells stably expressing P2Y1 were mixed with cells stably expressing P2Y2. P2Y1-expressing cells were identified by a change in $\left[\mathrm{Ca}^{2+}\right]_{i}$ after focal application of 2 meSADP (5 $\left.\mu \mathrm{M}\right)$, whereas P2Y2-expressing cells were identified by focal application of UTP $(50 \mu \mathrm{M})$ and are labeled with yellow circles (top row). A control Ca ${ }^{2+}$ wave was stimulated at $t=0$ sec by touching the indicated cell. The spread of the control wave at 5, 10,15, and 20 sec after stimulation is shown. The second column shows the spread of the Ca ${ }^{2+}$ wave in the same field of cells after incubation with apyrase ( $30 \mathrm{U} / \mathrm{ml}$ ) for $15 \mathrm{~min}$ (representative of 7 separate experiments). b, c, Representative traces of the 340/380 fura-2 emission ratios from individual cells in the experiment shown above during a control Ca $2+$ wave $(b)$ and during a $\mathrm{Ca}^{2+}$ wave in apyrase (c) (P2Y1-1321N1 cells are shown in blue, and P2Y2-1321N1 cells are shown in red). $d$, Comparison of the percentage of P2Y1-1321N1 and P2Y2-1321N1 cells that are engaged in control $\mathrm{Ca}^{2+}$ waves and in $\mathrm{Ca}^{2+}$ waves in the presence of apyrase. e, Comparison of the mean rate of $\mathrm{Ca}^{2+}$ wave propagation in P2Y1-1321N1 and P2Y2-1321N1 cells before and during incubation with apyrase.

pressed either P2Y1Rs or P2Y2Rs, respectively (compare with above).

In the cells that responded both to ADP and to UTP, we found that the mean rate of $\mathrm{Ca}^{2+}$ wave propagation was $11.7 \pm 0.7$ $\mu \mathrm{m} / \mathrm{sec}$ ( $n=56$ cells). To determine the effect of selectively blocking P2Y1Rs on $\mathrm{Ca}^{2+}$ wave propagation, we bath applied A3P5PS $(100 \mu \mathrm{M})$. A3P5PS prevented $\mathrm{Ca}^{2+}$ waves in $36 \%$ of cells responding to both ADP and UTP (control, $n=14$ cells in four fields; during A3P5PS, $n=9$ cells), indicating that P2Y1Rs were necessary for $\mathrm{Ca}^{2+}$ wave propagation in these cells. In these cells, the rate of $\mathrm{Ca}^{2+}$ wave propagation before applying A3P5PS was $7.7 \pm 1.1 \mu \mathrm{m} / \mathrm{sec}$. On the other hand, for cells in which $\mathrm{Ca}^{2+}$ waves persisted in A3P5PS, the propagation rate before applying this P2Y1R antagonist was $13.1 \pm 2.4 \mu \mathrm{m} / \mathrm{sec}$. Moreover, the rate of $\mathrm{Ca}^{2+}$ wave propagation was unaffected in these cells during A3P5PS (rate, $15.5 \pm 1.7 \mu \mathrm{m} / \mathrm{sec} ; p>0.1$ vs before A3P5PS).

To determine whether P2Y2Rs are required for $\mathrm{Ca}^{2+}$ wave propagation in cells expressing both $\mathrm{P} 2 \mathrm{Y} 1 \mathrm{Rs}$ and $\mathrm{P} 2 \mathrm{Y} 2 \mathrm{Rs}$, we investigated the effect of apyrase on $\mathrm{Ca}^{2+}$ waves. We examined 11 cells expressing P2Y1Rs and P2Y2Rs in two fields and found that propagation of $\mathrm{Ca}^{2+}$ waves to only two of these cells was blocked during bath application of apyrase. The $\mathrm{Ca}^{2+}$ waves that persisted during apyrase were suppressed by A3P5PS (100 $\mu \mathrm{M}$; data not shown), indicating that these waves depended on P2Y1Rs. The rate of $\mathrm{Ca}^{2+}$ wave propagation during apyrase application was $18.1 \pm 2.1 \mu \mathrm{m} / \mathrm{sec}$, which was significantly greater than the rate of P2Y1R-dependent $\mathrm{Ca}^{2+}$ waves without apyrase $(7.7 \pm 1.1$ $\mu \mathrm{m} / \mathrm{sec} ; p<0.05)$, as predicted from the effect of apyrase on $\mathrm{Ca}^{2+}$ wave propagation in P2Y1-1321N1 cells.

Thus, with coexpression of P2Y1Rs and P2Y2Rs, the requirement of the two receptor subtypes for the propagation of $\mathrm{Ca}^{2+}$ waves varies on a cell-to-cell basis: for approximately one-third of cells, P2Y1Rs are necessary for $\mathrm{Ca}^{2+}$ waves; for approximately one-fifth of cells, P2Y2Rs are necessary; and in the remaining cells, either receptor subtype is sufficient to support $\mathrm{Ca}^{2+}$ waves.

Apyrase suppresses $\mathrm{Ca}^{2+}$ waves and directs $\mathrm{Ca}^{2+}$ waves through $\mathrm{P} 2 \mathrm{Y} 1$ receptors in spinal astrocytes

In spinal astrocytes, the propagation of $\mathrm{Ca}^{2+}$ waves depends on P2Y1Rs in $\sim 35 \%$ of cells because this is the proportion of cells in which $\mathrm{Ca}^{2+}$ waves are blocked by A3P5PS (Fam et al., 2000). To determine whether P2Y2Rs are required for $\mathrm{Ca}^{2+}$ wave propagation in spinal astrocytes, we investigated the effect of apyrase. We found that apyrase prevented propagation of $\mathrm{Ca}^{2+}$ waves to 11 of the 60 cells examined (Fig. $8 a, c ; n=6$ fields), implying that $\mathrm{Ca}^{2+}$ waves required activation of $\mathrm{P} 2 \mathrm{Y} 2 \mathrm{Rs}$ in the affected cells. The spread of $\mathrm{Ca}^{2+}$ waves in the presence of apyrase was reversibly suppressed by applying A3P5PS (100 $\mu \mathrm{M}$; Fig. 8a,c), indicating that $\mathrm{Ca}^{2+}$ wave propagation during apyrase application is mediated by P2Y1Rs. The rate of propagation of the $\mathrm{Ca}^{2+}$ waves that persisted during apyrase was not different from the rate of wave propagation before applying apyrase (Fig. $8 b$ ). Thus, we conclude that for $\sim 20 \%$ of spinal astrocytes, $\mathrm{Ca}^{2+}$ wave propagation requires activation of P2Y2Rs. Also, during apyrase application, 


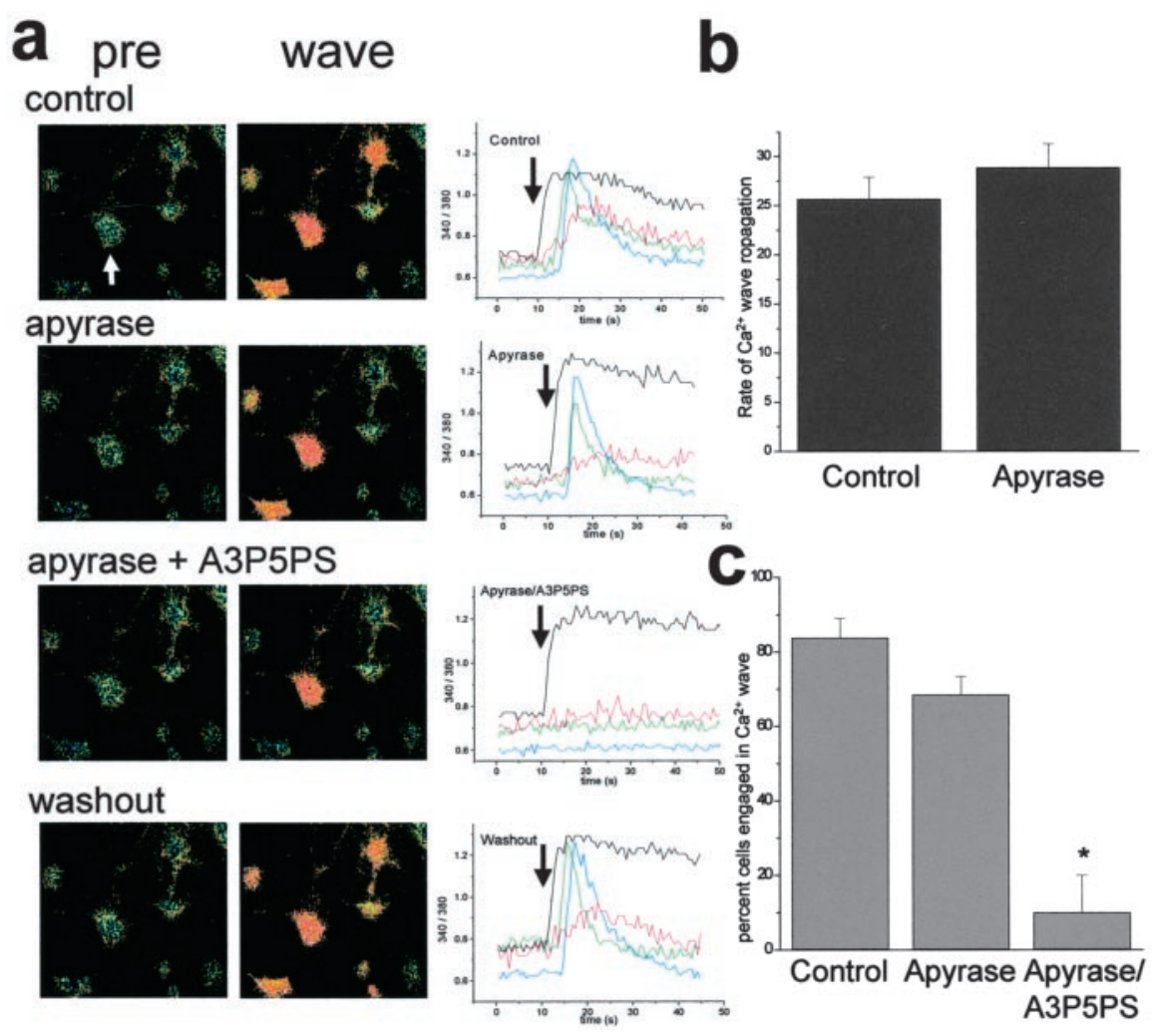

Figure 8. Apyrase diverts $\mathrm{Ca}^{2+}$ waves through P2Y1Rs in spinal astrocyte cultures. $\mathrm{Ca}^{2+}$ waves were stimulated in spinal astrocytes in the absence and then in the presence of the nucleotidase apyrase. $a$, The color panels on the left show the prestimulation (pre) resting $\left[\mathrm{Ca}^{2+}\right]_{\mathrm{i}}$ levels, whereas the panels in the middle show the maximum spread of the $\mathrm{Ca}^{2+}$ wave in control, apyrase $(30 \mathrm{U} / \mathrm{ml})$, apyrase and A3P5PS $(10 \mu \mathrm{m})$ together, and after washout. The cell stimulated is labeled with a white arrow. The right panels show the time course of the changes of the $340 / 380$ fura- 2 emission ratios in each cell during the $\mathrm{Ca}^{2+}$ wave. $b$, Comparison of the rate of $\mathrm{Ca}^{2+}$ wave propagation in spinal astrocytes in pair-matched control $\mathrm{Ca}^{2+}$ waves and $\mathrm{Ca}^{2+}$ waves in apyrase. In this series of experiments, the mean rate of astrocyte $\mathrm{Ca}^{2+}$ wave propagation was $23.5 \pm 1.9 \mu \mathrm{m} / \mathrm{sec}$, whereas in apyrase, the rate of propagation of the $\mathrm{Ca}^{2+}$ wave was $27.2 \pm 2.3 \mu \mathrm{m} / \mathrm{sec}(n=49$ cells in 6 fields). To determine whether in apyrase the $\mathrm{Ca}^{2+}$ waves were propagating by activation of P2Y1R, A3P5PS (10 $\left.\mu \mathrm{m}\right)$ was included in the bathing medium along with apyrase. $c$, Mean percentage of cells in each field that participated in the $\mathrm{Ca}^{2+}$ wave under control conditions, in apyrase ( $n=6$ fields), and in both apyrase and A3P5PS ( $n=2$ fields).

$\mathrm{Ca}^{2+}$ waves in spinal astrocytes are diverted away from P2Y2Rs and propagate through activation of P2Y1Rs.

\section{Discussion}

$\mathrm{P} 2 \mathrm{Y} 2$ is the UTP-activated $\mathrm{P} 2 \mathrm{Y}$ receptor in spinal astrocytes

That more than one subtype of P2YR is required for astrocyte $\mathrm{Ca}^{2+}$ waves was implied from previous findings that $\mathrm{Ca}^{2+}$ waves are blocked by broadly acting P2Y inhibitors but are only partially inhibited by the selective P2Y1R inhibitor A3P5PS. We therefore focused on identifying the P2YR mediating the A3P5PS-resistant ATP responses and $\mathrm{Ca}^{2+}$ waves in spinal astrocytes. By using RT-PCR, we demonstrated that in addition to P2Y1 (Fam et al., 2000), mRNA for P2Y2 is expressed in spinal dorsal horn cultures. Like the P2U receptor we had characterized previously, P2Y2Rs are activated by UTP, as well as by ATP, and are not affected by A3P5PS. P2Y2R function is blocked by suramin (Charlton et al., 1996), as are UTP-evoked $\mathrm{Ca}^{2+}$ responses in spinal astrocytes and the A3P5PS-resistant component of $\mathrm{Ca}^{2+}$ waves. Likewise, UTP-evoked $\mathrm{Ca}^{2+}$ responses and $\mathrm{Ca}^{2+}$ waves in spinal astrocytes are blocked by PPADS (discussed more fully below). The other P2YR subtype for which mRNA was detected in dorsal spinal cultures was $\mathrm{P} 2 \mathrm{Y} 4 . \mathrm{Ca}^{2+}$ responses mediated by recombinant rat P2Y4Rs were unaffected by suramin; thus, P2Y4R cannot account for the UTP-evoked response or A3P5PS- resistant component of $\mathrm{Ca}^{2+}$ waves in spinal astrocytes. The P2Y4 mRNA we detected may have been from nonastrocyte cell types found in the mixed spinal cord cultures used in the present study. Alternatively, P2Y4 mRNA might be present in spinal astrocytes but might not be translated, or translated protein may not reach the cell surface. Therefore, because the only functional UTP-activated P2YR we detected was P2Y2R, this fully accounts for the UTP-activated $\mathrm{Ca}^{2+}$ responses and the A3P5PS-resistant component of $\mathrm{Ca}^{2+}$ waves in spinal astrocytes.

Previously we found that UTPactivated $\mathrm{Ca}^{2+}$ responses in dorsal spinal astrocytes are competitively antagonized by PPADS (Ho et al., 1995). However, it has been reported that recombinant human P2Y2Rs are unaffected by PPADS (Charlton et al., 1996). On the basis of this pharmacological difference, we had suspected that the UTP-evoked response in spinal astrocytes might have been mediated via a P2YR that was not P2Y2. However, in the present study, we found that $\mathrm{Ca}^{2+}$ responses mediated by recombinant rat P2Y2Rs showed blockade by PPADS. Thus, there appears to be a rat versus human species difference in the sensitivity of the P2Y2R to PPADS. The primary sequence of the human $\mathrm{P} 2 \mathrm{Y} 2 \mathrm{R}$ is predicted to be $89 \%$ identical to that of the rat orthologue. The predicted ligand-interacting region of P2Y2R includes positively charged amino acids in the sixth and seventh transmembrane (TM) domains (Erb et al., 1995). Each of these TM domains has one conservative substitution: TM6, L248V; and TM7, I289V, which could potentially underlie the difference in sensitivity to PPADS. There are alternative regions that may account for this difference in the extracellular domains; thus, further studies are required to determine the molecular basis for the species difference in the sensitivity of P2Y2Rs to PPADS.

\section{Apyrase selectively inhibits $\mathrm{Ca}^{2+}$ waves mediated by P2Y2 but not $\mathrm{P} 2 \mathrm{Y} 1$ receptors}

There is currently no available pharmacological antagonist that differentially inhibits P2Y2Rs but not P2Y1Rs. However, we found that the nucleotidase apyrase selectively suppresses activation of P2Y2Rs by degrading endogenous ATP but maintains activation of P2Y1Rs, presumably by producing ADP. In spinal astrocytes, bath applying apyrase prevented $\mathrm{Ca}^{2+}$ wave propagation to $\sim 20 \%$ of cells, implying that activation of P2Y2Rs is necessary for $\mathrm{Ca}^{2+}$ waves to spread to these cells. This finding also demonstrates that even with apyrase in the extracellular bathing solution, $\mathrm{Ca}^{2+}$ waves persist in $\sim 80 \%$ of spinal astrocytes by activation of P2Y1Rs. In previous studies, apyrase has been found to suppress $\mathrm{Ca}^{2+}$ waves between cortical astrocytes (Cotrina et al., 1998b; Guthrie et al., 1999) and retinal astrocytes (Newman, 2001) and $\mathrm{Ca}^{2+}$ waves from retinal astrocytes to Muller cells (Newman, 2001). On the other hand, apyrase was reported to 
have no effect on $\mathrm{Ca}^{2+}$ waves in striatal astrocytes (Venance et al., 1997). This lack of effect of apyrase was interpreted as strong evidence against involvement of ATP in propagation of striatal astrocyte $\mathrm{Ca}^{2+}$ waves. But an alternative explanation is that $\mathrm{Ca}^{2+}$ waves in these astrocytes are mediated by ATP: the lack of effect of apyrase is consistent with waves mediated by P2Y1Rs or with waves mediated by P2Y2Rs in control conditions and by P2Y1Rs in the presence of apyrase. In the retina, apyrase has a much greater effect on astrocyte-Muller cell $\mathrm{Ca}^{2+}$ waves than on astrocyte-astrocyte $\mathrm{Ca}^{2+}$ waves (Newman, 2001), which may indicate that the relative contribution of $\mathrm{P} 2 \mathrm{Y} 2 \mathrm{Rs}$ versus $\mathrm{P} 2 \mathrm{Y} 1 \mathrm{Rs}$ is greater for astrocyte-Muller cell $\mathrm{Ca}^{2+}$ waves than for astrocyte-astrocyte waves. Generally, our findings with apyrase under conditions in which we differentially expressed P2Y1Rs, P2Y2Rs, or both demonstrate that the effect of this nucleotidase on $\mathrm{Ca}^{2+}$ wave propagation in a given system will be critically dependent on the subtype of P2YRs expressed.

\section{Distinctive characteristics of $\mathrm{Ca}^{2+}$ waves mediated by P2Y2Rs versus P2Y1Rs}

A striking finding of the present study is that $\mathrm{Ca}^{2+}$ waves mediated by $\mathrm{P} 2 \mathrm{Y} 2 \mathrm{Rs}$ propagate much more rapidly than do those mediated by P2Y1Rs, a difference accounted for by more rapid ATP-evoked $\mathrm{Ca}^{2+}$ responses of P2Y2Rs than of P2Y1Rs. The slower speed at which $\mathrm{Ca}^{2+}$ responses were produced by P2Y1Rs was not an intrinsic property of signaling via this receptor subtype because $\mathrm{Ca}^{2+}$ responses of P2Y1Rs evoked by ADP were as rapid as the ATP-stimulated responses of P2Y2Rs. As predicted from this difference in signaling, we found that $\mathrm{Ca}^{2+}$ waves mediated via P2Y1Rs were accelerated by facilitating the extracellular conversion of ATP to ADP by apyrase, an effect that would not have been expected from previous studies.

For $\mathrm{Ca}^{2+}$ waves to be mediated by ATP, the wave of increased $\left[\mathrm{Ca}^{2+}\right]_{\mathrm{i}}$ needs to be preceded by a rise in extracellular ATP, and this has been demonstrated in retina (Newman, 2001) and in hippocampal cultures (Wang et al., 2000). The time required for released ATP to reach sufficient concentrations to stimulate P2YRs is one main factor that determines the rate of spread of $\mathrm{Ca}^{2+}$ waves. The other principal factor determining the speed at which $\mathrm{Ca}^{2+}$ waves spread is the rate at which the stimulated P2YRs produce a rise in $\left[\mathrm{Ca}^{2+}\right]_{\mathrm{i}}$. As can be most readily seen in our studies in which we mixed cells expressing either P2Y1Rs or P2Y2Rs (e.g., Fig. 4), the relative contribution of these two factors may dramatically affect the speed of $\mathrm{Ca}^{2+}$ wave propagation. $\mathrm{Ca}^{2+}$ waves mediated by P2Y2Rs will tend toward the maximum rate allowed by the rise in extracellular ATP. On the other hand, waves mediated by P2Y1Rs will be markedly slower than the rise in extracellular ATP, owing to the additional signaling time required for activation of this receptor by ATP.

In the literature, a wide range of rates of propagation of astrocyte $\mathrm{Ca}^{2+}$ waves has been reported. These rates appear to cluster into a slower range of 5-10 $\mu \mathrm{m} / \mathrm{sec}$ (Dani et al., 1992; HarrisWhite et al., 1998; John et al., 1999) and a faster range of 13-25 $\mu \mathrm{m} / \mathrm{sec}$ (Nedergaard, 1994; Hassinger et al., 1996; Newman and Zahs, 1997; Venance et al., 1997; Schipke et al., 2002; present study). A potential explanation for the divergence in the rates of $\mathrm{Ca}^{2+}$ wave propagation is afforded by our present study: in preparations with the slower rates of propagation, it is possible that P2Y1Rs may have a predominant role in mediating $\mathrm{Ca}^{2+}$ waves, whereas in preparations with the more rapid rates, the P2Y2Rs might be dominant. Because signaling by G-protein-coupled receptors, such as P2YRs, is highly regulated in cells (Ferguson, 2001; Pierce et al., 2002), it is possible that the signal transduction rate of P2Y1Rs and P2Y2Rs might itself be subject to modification by a variety of intracellular processes. This may further contribute to divergence in rates and, in addition, may allow for context-dependent modulation of the rate of $\mathrm{Ca}^{2+}$ wave propagation.

\section{Gliotransmission via ATP and two subtypes of $\mathrm{P} 2 \mathrm{Y}$ receptors}

Propagation of $\mathrm{Ca}^{2+}$ waves by a diffusible chemical messenger is the principal form of astrocyte-astrocyte communication, increasingly referred to as gliotransmission. The preponderance of evidence indicates that the diffusible chemical messenger, or gliotransmitter, mediating $\mathrm{Ca}^{2+}$ waves is ATP. We have shown in the present study that in spinal astrocytes, two nucleotide receptors, $\mathrm{P} 2 \mathrm{Y} 1$ and $\mathrm{P} 2 \mathrm{Y} 2$, serve as gliotransmitter receptors detecting and responding to released ATP. These receptors are differentially activated by the gliotransmitter: P2Y2Rs mediate a fast response to extracellular ATP, whereas P2Y1Rs mediate a relatively slower response to ATP. Although either receptor subtype is sufficient to support $\mathrm{Ca}^{2+}$ waves, the rate and extent of the spread of the waves are governed by the subtype of gliotransmitter receptor engaged. Because ATP-mediated $\mathrm{Ca}^{2+}$ waves are observed in astrocytes in various regions of the CNS, we suggest that the concept of one gliotransmitter, ATP, and two gliotransmitter receptors, $\mathrm{P} 2 \mathrm{Y} 1$ and $\mathrm{P} 2 \mathrm{Y} 2$, may be a general principle of gliotransmission throughout the CNS. It is possible that there are regional or developmental differences in the relative contributions of these two receptor subtypes to $\mathrm{Ca}^{2+}$ waves. Additionally, within a given region, the expression or function of the receptors or both may be subject to regulation that may alter the dynamic properties of the spread of $\mathrm{Ca}^{2+}$ waves.

\section{References}

Araque A, Martin ED, Perea G, Arellano JI, Buno W (2002) Synaptically released acetylcholine evokes $\mathrm{Ca}^{2+}$ elevations in astrocytes in hippocampal slices. J Neurosci 22:2443-2450.

Bezzi P, Volterra A (2001) A neuron-glia signalling network in the active brain. Curr Opin Neurobiol 11:387-394.

Bogdanov YD, Wildman SS, Clements MP, King BF, Burnstock G (1998) Molecular cloning and characterization of rat P2Y4 nucleotide receptor. Br J Pharmacol 124:428-430.

Charles AC, Merrill JE, Dirksen ER, Sanderson MJ (1991) Intercellular signaling in glial cells: calcium waves and oscillations in response to mechanical stimulation and glutamate. Neuron 6:983-992.

Charlton SJ, Brown CA, Weisman GA, Turner JT, Erb L, Boarder MR (1996) PPADS and suramin as antagonists at cloned P2Y- and P2Upurinoceptors. Br J Pharmacol 118:704-710.

Cornell-Bell AH, Finkbeiner SM, Cooper MS, Smith SJ (1990) Glutamate induces calcium waves in cultured astrocytes: long-range glial signaling. Science 247:470-473.

Cotrina ML, Lin JH, Alves-Rodrigues A, Liu S, Li J, Azmi-Ghadimi H, Kang J, Naus CC, Nedergaard M (1998a) Connexins regulate calcium signaling by controlling ATP release. Proc Natl Acad Sci USA 95:15735-15740.

Cotrina ML, Lin JH, Nedergaard M (1998b) Cytoskeletal assembly and ATP release regulate astrocytic calcium signaling. J Neurosci 18:8794-8804.

Crack BE, Pollard CE, Beukers MW, Roberts SM, Hunt SF, Ingall AH, McKechnie KC, Ijzerman AP, Leff P (1995) Pharmacological and biochemical analysis of FPL 67156, a novel, selective inhibitor of ecto-ATPase. Br J Pharmacol 114:475-481.

Dani JW, Chernjavsky A, Smith SJ (1992) Neuronal activity triggers calcium waves in hippocampal astrocyte networks. Neuron 8:429-440.

Erb L, Garrad R, Wang Y, Quinn T, Turner JT, Weisman GA (1995) Sitedirected mutagenesis of P2U purinoceptors: positively charged amino acids in transmembrane helices 6 and 7 affect agonist potency and specificity. J Biol Chem 270:4185-4188.

Fam SR, Gallagher CJ, Salter MW (2000) P2Y(1) purinoceptor-mediated $\mathrm{Ca}(2+)$ signaling and $\mathrm{Ca}(2+)$ wave propagation in dorsal spinal cord astrocytes. J Neurosci 20:2800-2808.

Ferguson SS (2001) Evolving concepts in G protein-coupled receptor endo- 
cytosis: the role in receptor desensitization and signaling. Pharmacol Rev 53:1-24.

Guan X, Cravatt BF, Ehring GR, Hall JE, Boger DL, Lerner RA, Gilula NB (1997) The sleep-inducing lipid oleamide deconvolutes gap junction communication and calcium wave transmission in glial cells. J Cell Biol 139:1785-1792.

Guthrie PB, Knappenberger J, Segal M, Bennett MV, Charles AC, Kater SB (1999) ATP released from astrocytes mediates glial calcium waves. J Neurosci 19:520-528.

Harris-White ME, Zanotti SA, Frautschy SA, Charles AC (1998) Spiral intercellular calcium waves in hippocampal slice cultures. J Neurophysiol 79:1045-1052.

Hassinger TD, Guthrie PB, Atkinson PB, Bennett MV, Kater SB (1996) An extracellular signaling component in propagation of astrocytic calcium waves. Proc Natl Acad Sci USA 93:13268-13273.

Ho C, Hicks J, Salter MW (1995) A novel P2-purinoceptor expressed by a subpopulation of astrocytes from the dorsal spinal cord of the rat. Br J Pharmacol 116:2909-2918.

John GR, Scemes E, Suadicani SO, Liu JS, Charles PC, Lee SC, Spray DC, Brosnan CF (1999) IL-1beta differentially regulates calcium wave propagation between primary human fetal astrocytes via pathways involving P2 receptors and gap junction channels. Proc Natl Acad Sci USA 96:11613-11618.

King BF, Townsend-Nicholson A, Burnstock G (1998) Metabotropic receptors for ATP and UTP: exploring the correspondence between native and recombinant nucleotide receptors. Trends Pharmacol Sci 19:506-514.

Neary JT, van Breemen C, Forster E, Norenberg LO, Norenberg MD (1988) ATP stimulates calcium influx in primary astrocyte cultures. Biochem Biophys Res Commun 157:1410-1416.

Nedergaard M (1994) Direct signaling from astrocytes to neurons in cultures of mammalian brain cells. Science 263:1768-1771.

Newman EA (2001) Propagation of intercellular calcium waves in retinal astrocytes and Muller cells. J Neurosci 21:2215-2223.

Newman EA, Zahs KR (1997) Calcium waves in retinal glial cells. Science 275:844-847.
Newman EA, Zahs KR (1998) Modulation of neuronal activity by glial cells in the retina. J Neurosci 18:4022-4028.

North RA, Barnard EA (1997) Nucleotide receptors. Curr Opin Neurobiol 7:346-357.

Parr CE, Sullivan DM, Paradiso AM, Lazarowski ER, Burch LH, Olsen JC, Erb L, Weisman GA, Boucher RC, Turner JT (1994) Cloning and expression of a human P2U nucleotide receptor, a target for cystic fibrosis pharmacotherapy. Proc Natl Acad Sci USA 91:3275-3279.

Peterson ER, Crain SM (1982) Nerve growth factor attenuates neurotoxic effects of taxol on spinal cord-ganglion explants from fetal mice. Science 217:377-379.

Pierce KL, Premont RT, Lefkowitz RJ (2002) Seven-transmembrane receptors. Nat Rev Mol Cell Biol 3:639-650.

Salter MW, Hicks JL (1994) ATP-evoked increases in intracellular calcium in neurons and glia from the dorsal spinal cord. J Neurosci 14:1563-1575.

Sambrook J, Russell DW (2001) Molecular cloning, Ed 3. Cold Spring Harbor, NY: Cold Spring Harbor Laboratory.

Schipke CG, Boucsein C, Ohlemeyer C, Kirchhoff F, Kettenmann H (2002) Astrocyte $\mathrm{Ca} 2+$ waves trigger responses in microglial cells in brain slices. FASEB J 16:255-257.

Varadaraj K, Skinner DM (1994) Denaturants or cosolvents improve the specificity of PCR amplification of a G + C-rich DNA using genetically engineered DNA polymerases. Gene 140:1-5.

Venance L, Stella N, Glowinski J, Giaume C (1997) Mechanism involved in initiation and propagation of receptor-induced intercellular calcium signaling in cultured rat astrocytes. J Neurosci 17:1981-1992.

Vernadakis A (1996) Glia-neuron intercommunications and synaptic plasticity. Prog Neurobiol 49:185-214.

Wang Z, Haydon PG, Yeung ES (2000) Direct observation of calciumindependent intercellular ATP signaling in astrocytes. Anal Chem 72:2001-2007.

Westfall TD, Kennedy C, Sneddon P (1997) The ecto-ATPase inhibitor ARL 67156 enhances parasympathetic neurotransmission in the guinea-pig urinary bladder. Eur J Pharmacol 329:169-173.

Zimmermann H (2000) Extracellular metabolism of ATP and other nucleotides. Naunyn Schmiedebergs Arch Pharmacol 362:299-309. 